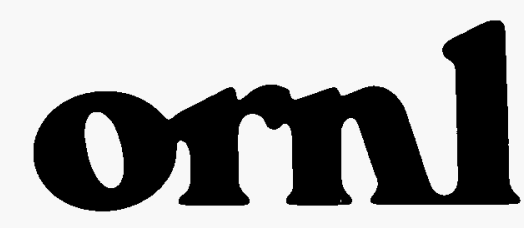

OAK RIDGE NATIONAL LABORATORY

MARTIN MARUETRA
RECEIVED

JUL 181995

OSTI

ENVIRONMENTAL RESOURCES OF SELECTED AREAS OF HAWAII:

GEOLOGICAL HAZARDS

\author{
by \\ William P. Staub \\ Robert M. Reed, \\ Project Manager
}

MANAGED BY

MARTIN MARIETTA ENERGY SYSTEMS, INC.

FOR THE UNITED STATES

DEPARTMENT OF ENERGY

DISTRIBUTION OF THIS DOCLUMEENT IS UNLIMITED 
This report has been reproduced directly from the best available copy.

Available to DOE and DOE contractors from the Office of Scientific and Technical Information, P.O. Box 62, Oak Ridge, TN 37831; prices avallable from (615) 576-8401, FTS 626-8401.

Available to the public from the National Technical Information Service, U.S. Department of Commerce, 5285 Port Royal Rd., Springtield, VA 22161.

This report was prepared as an account of work sponsored by an agency of the United States Government. Neither the United States Government nor any agency thereof, nor any of their employees, makes any warranty, express or implied, or assumes any legal liability or responsibility for the accuracy, completeness, or usefulness of any information, apparatus, product, or process disclosed, or represents that its use would not infringe privately owned rights. Reference herein to any specific commercial product, process, or service by trade name, trademark, manufacturer, or otherwise, does not necessarily constitute or imply its endorsement, recommendation, or favoring by the United States Government or any agency thereof. The views and opinions of authors expressed herein do not necessarily state or reflect those of the United States Government or any agency thereof. 


\section{DISCLAIMER}

Portions of this document may be illegible in electronic image products. Images are produced from the best available original document. 


\title{
ENVIRONMENTAL RESOURCES OF SELECTED AREAS OF HAWAII: GEOLOGICAL HAZARDS
}

\author{
William P. Staub \\ Robert M. Reed, Project Manager \\ Energy Division
}

March 1995

Prepared for U.S. Department of Energy Oak Ridge Operations Office

\author{
by \\ OAK RIDGE NATIONAL LABORATORY \\ Oak Ridge, Tennessee 37831 \\ managed by \\ MARTIN MARIETTA ENERGY SYSTEMS, INC. \\ for the \\ U.S. DEPARTMENT OF ENERGY \\ under contract DE-AC05-84OR21400
}

DISTRIBUTION OF THIS DOCLUNENT IS UNLIMITED 
[Blank Page] 
LIST OF FIGURES $\ldots \ldots \ldots \ldots \ldots \ldots \ldots \ldots \ldots \ldots \ldots \ldots \ldots \ldots \ldots \ldots$

LIST OF TABLES $\ldots \ldots \ldots \ldots \ldots \ldots \ldots \ldots \ldots \ldots \ldots \ldots \ldots \ldots \ldots \ldots \ldots$

ACRONYMS AND ABBREVIATIONS $\ldots \ldots \ldots \ldots \ldots \ldots \ldots \ldots \ldots \ldots \ldots \ldots$ ix

1. INTRODUCTION $\ldots \ldots \ldots \ldots \ldots \ldots \ldots \ldots \ldots \ldots \ldots \ldots \ldots \ldots \ldots \ldots$

2. THE HAWAIIAN ISLANDS $\ldots \ldots \ldots \ldots \ldots \ldots \ldots \ldots \ldots \ldots \ldots \ldots \ldots \ldots \ldots$

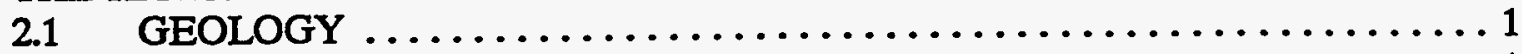

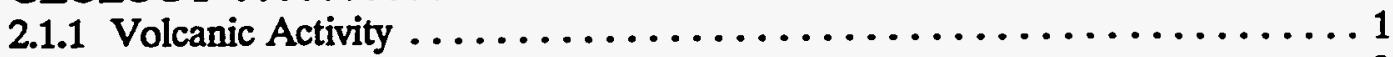

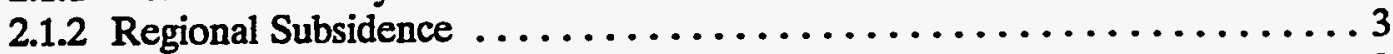

2.1 .3 Large-Scale Submarine Landslides $\ldots \ldots \ldots \ldots \ldots \ldots \ldots \ldots \ldots \ldots$

2.1.4 Small-Scale Submarine Landslides $\ldots \ldots \ldots \ldots \ldots \ldots \ldots \ldots \ldots \ldots$

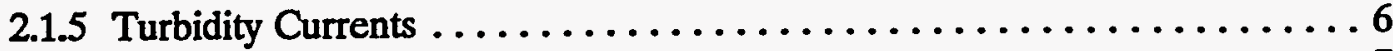

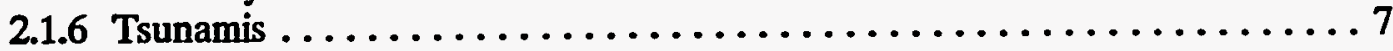

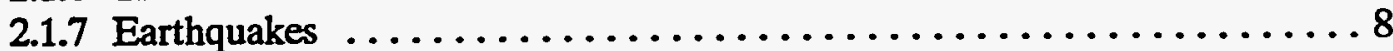

2.1 .8 Geologic Hazard Zones . . . . . . . . . . . . . . . . . 10

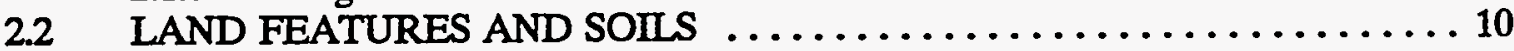

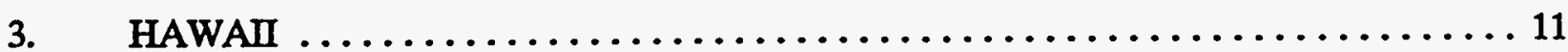

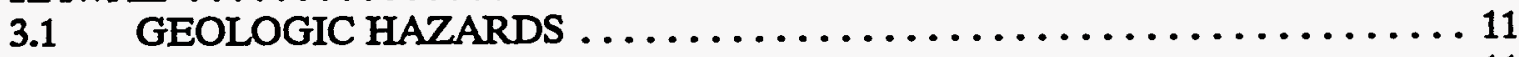

3.1.1 Volcanic Activity . . . . . . . . . . . . . . . . . . . . . 11

3.1.2 Earthquake and Earthquake-Induced Hazards .............. 17

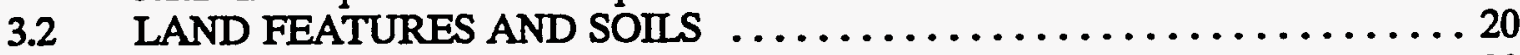

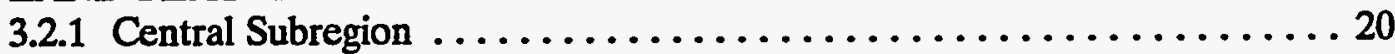

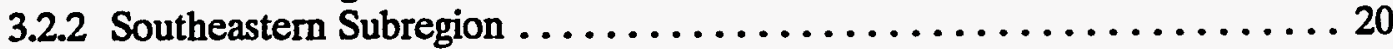

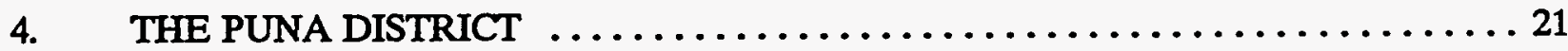

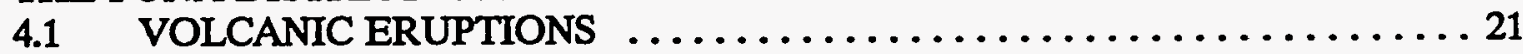

4.2 RAPID SURFACE DEFORMATION ALONG ACTIVE

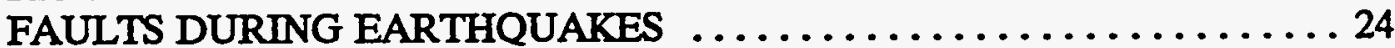

4.3 LONG-TERM SURFACE DEFORMATION ................ 28

4.4 EARTHQUAKE PROBABILITIES IN THE PUNA DISTRICT

AND ADJACENT REGIONS ...................... 28

5. SUMMARY OF PROBABILISTIC ESTIMATES FOR TECTONIC

ACTIVITY IN THE HAWAIIAN ISLANDS $\ldots \ldots \ldots \ldots \ldots \ldots \ldots \ldots \ldots \ldots \ldots . \ldots \ldots$

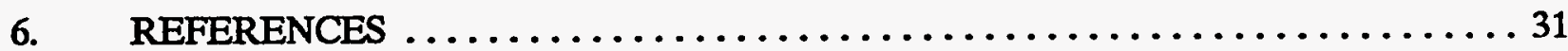

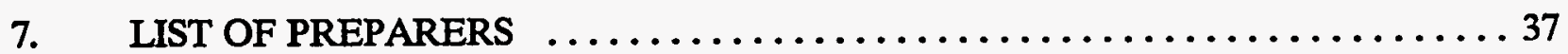


[Blank Page] 


\section{LIST OF FIGURES}

Fiqure

$\underline{\text { Page }}$

1 Large-scale submarine landslides in the Hawaiian Islands. $\ldots \ldots \ldots \ldots \ldots \ldots \ldots$

2 Uniform Building Code seismic zone map of the State of Hawaii $\ldots \ldots \ldots \ldots \ldots$

3 Volcanoes and lava hazard zones in Hawaii. .................... 12

4 Tephra (volcanic ash) hazard zones on Hawaii $\ldots \ldots \ldots \ldots \ldots \ldots \ldots \ldots$

5 Ground failure hazard zones on Hawaii $\ldots \ldots \ldots \ldots \ldots \ldots \ldots \ldots \ldots \ldots$

6 Historic storage-motion earthquakes on Hawaii $\ldots \ldots \ldots \ldots \ldots \ldots \ldots \ldots$

$7 \quad$ Volcanic landforms in the lower east rift zone $\ldots \ldots \ldots \ldots \ldots \ldots \ldots \ldots \ldots \ldots$

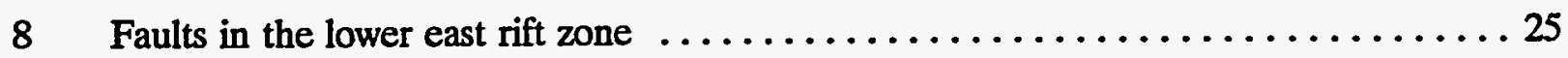

9 Fault zones on the south flanks of Mauna Loa and Kilauea . . . . . . . . . . 27 
[Blank Page]

vi 


\section{LIST OF TABLES}

Table

Page

1 Location, ages, and stages of volcanoes in Hawaii $\ldots \ldots \ldots \ldots \ldots \ldots \ldots \ldots$

2 Hazard zones for lava flows on Hawaii $\ldots \ldots \ldots \ldots \ldots \ldots \ldots \ldots \ldots \ldots$

3 Historical earthquakes of magnitude $\geq 6$ since 1868 on Hawaii $\ldots \ldots \ldots \ldots \ldots$

4 Conditional probability estimates for earthquakes in the Hawaiian

archipelago and in the southern parts of the island of Hawaii . . . . . . . . . . 29

5 Probabilities of inundation during a 50-year time interval

by lava along the MERZ and LERZ of Kilauea and along various

slopes outside rift zones of Kiluea and Mauna Loa . . . . . . . . . . . . 30

6 Peak ground accelerations with $10 \%$ probability of being exceeded

for various time intervals and locations on the south

side of Hawaii 
[Blank Page] 


\section{ACRONYMS AND ABBREVIATIONS}

$\begin{array}{ll}\mathrm{ft} & \text { foot } \\ \mathrm{g} & \text { gram } \\ \mathrm{g} & \text { acceleration due to gravity } \\ \text { GLORIA } & \text { Geological Long-Range Inclined Asdic } \\ \mathrm{km} & \text { kilometers } \\ \mathrm{ICBO} & \text { International Conference of Building Officials } \\ \text { in } & \text { inch } \\ \mathrm{LERZ} & \text { lower east rift zone } \\ \mathrm{m} & \text { meter } \\ \mathrm{MERZ} & \text { middle east rift zone } \\ \text { mile } & \text { square mile } \\ \text { mm } & \text { millimeter } \\ \text { PGA } & \text { peak ground acceleration } \\ \text { s } & \text { second } \\ \text { SeaMARC } & \text { Seafloor Mapping and Remote Characterization } \\ \text { UBC } & \text { Uniform Building Code } \\ \text { UERZ } & \text { upper east rift zone } \\ \text { USDA } & \text { U.S. Department of Agriculture } \\ \text { USGS } & \text { U.S. Geological Survey }\end{array}$


[Blank Page] 


\section{INTRODUCTION}

This report has been prepared to make available and archive the background scientific data and related information collected on geologic hazards during the preparation of the environmental impact statement (EIS) for Phases 3 and 4 of the Hawaii Geothermal Project (HGP) as defined by the state of Hawaii in its April 1989 proposal to Congress. The U.S. Department of Energy (DOE) published a notice in the Federal Register on May 17, 1994 (Fed. Regis. 59, 25638) withdrawing its Notice of Intent (Fed. Regis. 57, 5433) of February 14, 1992, to prepare the HGP-EIS. Since the state of Hawaii is no longer pursuing or planning to pursue the HGP, DOE considers the project to be terminated.

This report presents a review of current information on geologic hazards in the Hawaiian Islands. Interrelationships among these hazards are discussed. Probabilities of occurrence of given geologic hazards are provided in various regions where sufficient geologic or historical data are available. Most of the information contained herein is compiled from recent U.S. Geological Survey (USGS) publications and USGS open-file reports related to this project. This report describes the natural geologic hazards present in the area and does not represent an assessment of environmental impacts.

Geologic hazards originate both onshore and offshore. Onshore geologic hazards such as volcanic eruptions, earthquakes, surface rupture, landslides, uplift, and subsidence occur mainly on the southern third of the island of Hawaii (hereinafter referred to as Hawaii). Offshore geologic hazards are more widely distributed throughout the Hawaiian Islands. Examples of offshore geologic hazards are submarine landslides, turbidity currents, and seismic sea waves (tsunamis).

First, overviews of volcanic and earthquake activity, and details of offshore geologic hazards are provided for the Hawaiian Islands. Then, a more detailed discussion of onshore geologic hazards is presented, with special emphasis on the southern third of Hawaii and the east rift zone of Kilauea.

\section{THE HAWAIIAN ISLANDS}

\section{GEOLOGY}

\subsubsection{Volcanic Activity}

The Hawaiian Island segment of the Hawaiian-Emperor Seamount chain consists of a chain of shield volcanoes $640 \mathrm{~km}$ ( 400 miles) long that extends from the island of Hawaii to the island of Kauai. The youngest of these islands, Hawaii, is still forming, and the islands become progressively older to the northwest (Clague and Dalrymple 1987). Age estimates for the oldest volcanoes (on the island of Kauai) range from 3.9 to 5.8 million years (Pliocene). Table 1 lists the ages of shield-building stages of volcanic activity on Hawaii, Maui, Molokai, Oahu, and Kauai. 
Table 1. Location, ages, and stages of volcanoes in Hawaii

\begin{tabular}{lcl}
\hline Island & $\begin{array}{c}\text { Age } \\
\text { (millions of years) }\end{array}$ & $\begin{array}{l}\text { Current } \\
\text { stage }\end{array}$ \\
\hline Kauai & 3.9 to 5.8 & Post-shield \\
Oahu & 2.3 to 3.5 & Post-shield \\
West Molokai & 1.8 & Post-shield \\
East Molokai & 1.3 to 1.5 & Post-shield \\
West Maui & 1.15 to 1.3 & Post-shield \\
East Maui & 0.8 & Post-shield \\
Hawaii & $<1.0$ & Shield-building \\
\hline
\end{tabular}

"Kilauea and Mauna Loa only.

Source: Clague and Dalrymple 1987.

Volcanoes near the peaks of their shield-building stages in the Hawaiian Island chain rise off the ocean floor from depths exceeding $5.7 \mathrm{~km}$ ( 3.5 miles) and reach maximum heights exceeding $4 \mathrm{~km}$ ( 2.5 miles) above sea level. Uneroded submarine and subaerial slopes of these volcanoes average about 13 degrees and 4 degrees, respectively, from about $0.5 \mathrm{~km}$ ( 0.3 miles) below sea level to about $1.0 \mathrm{~km}$ (0.6 miles) above sea level (Mark and Moore 1987).

Hawaiian Island volcanoes are among the largest and most active on earth. The greatest growth occurs during the shield-building stage (95 to 98\%), which lasts about 0.5 million years (Moore and Clague 1992). Only Mauna Loa and Kilauea (the two southeasternmost volcanoes on Hawaii) and Loihi (a submarine volcano off the south coast of Hawaii) are still in their shieldbuilding stages. These three volcanoes frequently erupt large volumes of lava.

Although other Hawaiian volcanoes may occasionally erupt, their life cycles are beyond the shield-building stage. Such eruptions generally are small and infrequent. East Maui (Haleakala) is the site of the only historical eruption (1790) in the Hawaiian Island chain that did not occur on Hawaii. Hualalai (on Hawaii) last erupted in 1801. Although small eruptions have occurred on Mauna Kea during prehistoric Holocene time, shield-building activity is believed to have ceased there in late Pleistocene time. Pleistocene eruptions also occurred on Kohala, where shield-building has ceased.

Statewide volcanic activity as described above suggests that voluminous lava flows, lava fountains, and pyroclastic eruptions occur only on Kilauea and Mauna Loa on Hawaii. Frequencies of volcanic activity are discussed in Sect. 3. 


\subsection{Regional Subsidence}

Shield-building volcanic activity is accompanied by regional subsidence of the oceanic crust on which the volcanoes grow. Regional subsidence continues at a diminishing rate long after shield-building ceases. The rate of subsidence is greatest near the southeastern (youngest) end of the Hawaiian Island chain. Estimated subsidence for drowned reefs off the northwest coast of Hawaii has averaged $2.6 \pm 0.4 \mathrm{~mm} /$ year $(0.7 \pm 0.1 \mathrm{in}$./year) over the last 463,000 years (Moore and Clague 1992), with a total of $1,335 \mathrm{~m}(4,380 \mathrm{ft})$ of subsidence having occurred. Much of this subsidence is attributed to shield-building activity on Mauna Loa. Seismic reflection data suggest that subsidence has virtually ceased offshore from Kauai (the northwesternmost and oldest of the main islands of Hawaii), where shield-building ended about 4 million years ago (Rees, Detrick, and Coakley 1993).

\subsubsection{Large-Scale Submarine Landslides}

Early evidence of large-scale submarine landslides on the flanks of the Hawaiian Ridge was based on generalized bathymetry, which has since been confirmed with Geological LongRange Inclined Asdic (GLORIA, sidescanning sonar) surveys (J. G. Moore et al. 1989; Moore, Normark, and Gutmacher 1992). The areal extent of large-scale landslides has been documented by J. G. Moore et al. (1989). Landslides off the northeast and southwest sides of the Hawaiian Island chain and off the southeast coast of Hawaii are shown in Fig. 1. Two major types of submarine landslide are recognized: (1) slumps that move downslope slowly and intermittently, and (2) debris avalanches that are episodes of rapid downslope movement. At least 17 large-scale submarine landslide areas were recognized, and multiple slides were observed to override one another in some areas. Large-scale failures may occur about every 100,000 years. At least 40 separate large-scale landslides have been mapped along the entire Hawaiian Ridge (Moore, Normark, and Gutmacher 1992). These submarine landslide areas cover about $100,000 \mathrm{~km}^{2}$ $\left(38,400\right.$ mile $\left.^{2}\right)$ of the ocean floor, over five times the land area of the Hawaiian Island chain that is above sea level.

Large-scale landslides are an integral part of the growth processes of oceanic volcanoes (Holcomb and Searle 1991). By the end of active growth, the major part of the volcanic edifice may be debris from repeated failures during growth. Individual failures may remove as much as half the subaerial part of a volcano and 10 to $20 \%$ of the entire edifice.

Two triggering mechanisms have been proposed for large-scale submarine landslides. One mechanism, which has been proposed for the landslides in the vicinity of Italy's Mt. Etna, is that the weight of the volcanic edifice formed on the seafloor causes the volcano to spread laterally by thrusting along mechanically weak, unconsolidated seafloor sediments (Delaney 1992). A second mechanism, which has been proposed for a Hawaiian volcano, is that forceful injection of magma along the volcano's rift zones initiates slumping and sliding of the volcano (Lipman et al. 1985). The pressure of injection pushes the sides of the volcano seawaid along mechanically weak glide- 


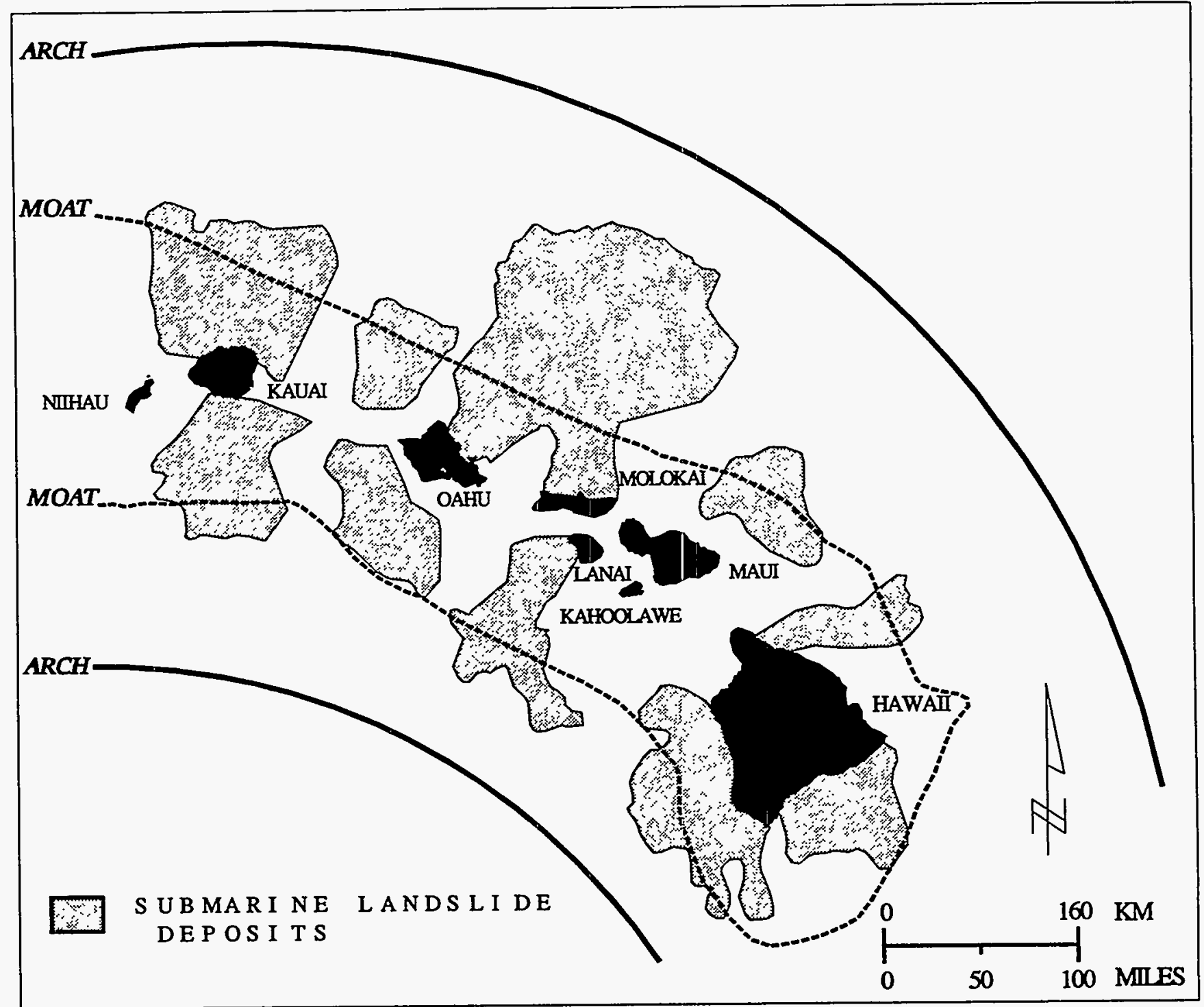

Fig. 1. Large-scale submarine landslides in the Hawaiian Islands. Source: Moore et al. 1989. 
planes consisting of unconsolidated seafloor sediments. All the landslides shown in Fig. 1 move toward the open sea, where the toe of the volcanic edifice is unbuttressed by an adjacent landmass. Ultimately, gravitational forces are responsible for this repositioning of the volcano's mass from areas of high to low elevation. The difference between Delaney's and Lipman's failure mechanisms is that the former does not require flanking volcanic eruptions. If Delaney's mechanism is applicable to Hawaiian volcanoes, large-scale landslides could continue beyond the shield-building phase of volcanism (the only requirement being that the volcano is still highstanding).

Large-scale submarine landslides result from steep and unbuttressed (unstable) slopes coupled with seismic activity associated with volcanic eruptions along active rift zones (Torresan et al. 1988). Steep slopes facing other islands are stable (buttressed), whereas steep slopes facing the open sea are unstable (unbuttressed). Interisland channels near the axis of the Hawaiian Ridge are buttressed and appear to be relatively free of large-scale submarine landslides.

Landslide debris collects on the seafloor at and beyond the foot of the volcanic edifice. The seafloor adjacent to the volcanic edifice is referred to as a flexural moat by Rees, Detrick, and Coakley (1993). The moat was created by construction of the volcanic edifice accompanied by regional subsidence of the oceanic crust. The axis of the moat is partially filled in with sediments from the Hawaiian Islands. The moat completely surrounds the island chain at distances ranging from about 50 to $100 \mathrm{~km}$ (30 to 60 miles) offshore (Fig. 1).

A stratigraphic description of the Hawaiian flexural moat based on seismic reflection surveys off the northeast shore of the Hawaiian Island chain has been developed by Rees, Detrick, and Coakley (1993). Significant findings are summarized as follows: (1) the moat is underfilled at the southeast end of the chain; (2) large-scale landslide deposits thicken progressively toward the northwest (older) end of the chain, from almost no deposits off the southeastern shore of Hawaii to deposits more than $2 \mathrm{~km}$ (1.2 miles) thick off the northeastern coast of Oahu; and (3) landslides are episodic. These findings suggest that large-scale submarine landslides continue long after shield-building volcanic activity ceases. Although volcanically active rift zones may contribute to large-scale submarine landslides, it has yet to be shown that they must be present for such events to occur.

In summary, at least $\mathbf{4 0}$ areas of large-scale submarine landslides have been identified along the Hawaiian Island chain (Moore, Normark, and Gutmacher 1992; Moore, Normark, and Holcomb 1994). Most of these areas (especially the older northwestern end of the chain) have experienced multiple landslide episodes. Episodic submarine debris avalanches have relatively long recurrence intervals (measured in tens or hundreds of thousands of years), but they would be catastrophic in their effects on the marine environment. Locally large tsunamis could be induced by large-scale, catastrophic debris avalanches. Probabilistic estimates and recurrence intervals of these phenomena are discussed in Sect. 5. 


\subsubsection{Small-Scale Submarine Landslides}

Small-scale submarine landslides may be caused by tectonic processes as described above. They also may be caused by storm surges or other submarine erosion processes. Subaerial mudflows in stream valleys may extend into the ocean as submarine landslides. Winters and Lee (1982) hypothesize that most deepwater failures are earthquake-induced. GLORIA images and standard geophysical surveying methods detect only the largest of landslide deposits. Many smaller events remain undetected but have the potential for producing catastrophic tsunamis along the coastal Hawaiian Island areas (Normark and Herring 1993).

SeaMARC II (Seafloor Mapping and Remote Characterization) side-scanning sonar surveys off the south coast of Maui have shown a number of acoustic shadows which are interpreted as hummocky ocean floor (Fornari and Campbell 1987). Landslide debris commonly is associated with hummocky surfaces. The ocean floor on the Maui side of Alenuihaha Channel is largely composed of hummocky ocean floor surrounding narrow and elongate strips of outcropping rock. The landslide debris appears to be relatively thin because the underlying rock would have been completely covered by a large-scale submarine landslide. The ocean floor on the Hawaii side of Alenuihaha Channel is largely composed of outcropping rock and is free of hummocky ocean floor, suggesting that small-scale submarine landslides may be less frequent in some areas than in others. Probabilistic estimates and recurrence intervals of these phenomena are discussed in Sect. 5.

\subsubsection{Turbidity Currents}

Turbidity currents differ from submarine landslides in that they contain a much higher percentage of water. They are much denser than pure water because large quantities of sediment are suspended within them. Turbidity currents that move downslope along the seafloor are capable of transporting and depositing large volumes of sediment into deep water, and they sometimes scour the seafloor over such flows. Turbidity currents carry large volumes of sediment as bedload and often cause significant erosion on low-angle slopes (Normark and Herring 1993). Initiation of turbidity currents is greatly enhanced on the steep slopes along the flanks of Hawaiian volcanoes.

Turbidity currents in the Hawaiian Islands may be initiated by submarine landslides, sediment disturbance by storm surges, tsunamis, slope destabilization by earthquakes, and deepwater currents (Normark and Herring 1993). Turbidity currents are known to travel at high speed for long distances and cause destruction of undersea telecommunication cables, even on gentle slopes.

Heezen and Ewing (1952) were the first to attribute the disruption of submarine telecommunication cables to the flow of turbidity currents. They concluded that the 1929 Grand Banks earthquake off Canada's east coast caused a submarine landslide that, in turn, caused a turbidity current. Based on distances between cable breaks and the times of these breaks, speeds 
of these currents were determined to be in excess of $20 \mathrm{~m} / \mathrm{s}(66 \mathrm{ft} / \mathrm{s})$. Krause et al. (1970) document similar cable breaks in the western Pacific Ocean, with maximum current speeds ranging between 8.5 and $14 \mathrm{~m} / \mathrm{s}$ ( 27 and $46 \mathrm{ft} / \mathrm{s}$ ).

Measurements of sediment transport and turbidity current flow resulting from the passage of Hurricane Iwa between Oahu and Kauai on November 23, 1982, showed that current meters moored in water at depths between 100 and $760 \mathrm{~m}$ (330 and $2500 \mathrm{ft}$ ) moved downslope for distances ranging up to $2.4 \mathrm{~km}$ (1.5 miles) (Dengler et al. 1984a, b). Telecommunication cables at depths between 1000 and $2000 \mathrm{~m}$ ( 3300 and $6600 \mathrm{ft}$ ) were damaged or buried by sediment during the hurricane-induced event. Measured velocities within the turbidity current ranged from 0.3 to $3.0 \mathrm{~m} / \mathrm{s}(1.0$ to $9.8 \mathrm{ft} / \mathrm{s})$.

The Hawaiian Islands shorelines include turbidite layers (sediments deposited by turbidity currents) in core samples from the seafloor at distances ranging up to $50 \mathrm{~km}$ (30 miles) from the base of Hawaiian volcanic slopes (Clague et al. 1988) and turbidites in the Hawaiian Deep, about $300 \mathrm{~km}$ (190 miles) offshore from Hawaii (Dziewonski, Wilkens, and Firth 1992). The upper surfaces of these turbidites are about $370 \mathrm{~m}$ (1160 ft) above the surrounding ocean floor. The physical characteristics of numerous documented turbidite deposits adjacent to the southeastern Hawaiian Islands (Normark and Herring 1993) are being evaluated.

\subsubsection{Tsunamis}

More than 130 historic tsunamis (seismic sea waves) have struck the Hawaiian Islands (Lander and Lockridge 1989). Thirty of these caused damage on one or more of the islands between 1819 and 1960 (Cox and Mink 1963).

Data collected for 15 destructive tsunamis in the Hawaiian Islands between 1900 and 1983 (Lockridge and Smith 1984) show that all but one struck Hawaii and at least four struck the

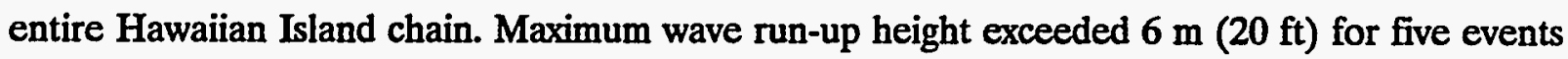
on Hawaii and for one event throughout the entire Hawaiian Island chain. Seven tsunamis were caused by local sources [one earthquake along the west coast of Hawaii, three earthquakes along the south coast of Hawaii, one volcanic eruption (location uncertain), and two unknown Hawaiian sources]. Sources of the eight other tsunamis were widely scattered earthquakes around the Pacific Rim (Japan, the Kurile Islands, the Aleutian Islands, and Chile). Three of the distant sources caused wave run-ups that exceeded $6 \mathrm{~m}(20 \mathrm{ft})$ on Hawaii.

Earthquakes on the Pacific Rim are capable of causing tsunami wave height run-ups in excess of $10 \mathrm{~m}$ ( $33 \mathrm{ft})$. The tsunami of May 23, 1960, which originated during an earthquake off the Chilean coast, recorded wave run-up that generally varied between 1 and $5 \mathrm{~m}$ ( 3 and $16 \mathrm{ft}$ ) throughout the Hawaiian Islands and reached as high as $10 \mathrm{~m}$ (30 ft) at Hilo (Cox and Mink 1963). The tsunami that struck the islands on April 1, 1946, has been attributed to an earthquake and seafloor movement on the north slope of the Aleutian trench (Shepard, Macdonald, and Cox 1950). This tsunami had a maximum wave height run-up of $16 \mathrm{~m}(52 \mathrm{ft})$ at Hilo. 
Large-scale submarine landslides may be capable of causing larger tsunamis than any of those historically recorded in the Hawaiian Islands. Gravel deposits derived from broken coral reefs are scattered about the Hawaiian Islands at elevations ranging from slightly above sea level

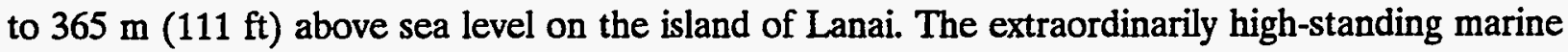
deposits (those which cannot be attributed to storm surge or eustatic change in sea level) may have been the result of local uplift (Stearns 1966). However, the interpretation of local uplift of this magnitude may be incompatible with long-term regional subsidence of the oceanic crust in response to crustal loading by shield-building volcanoes (Moore and Moore 1984). An alternative hypothesis is that high-standing marine deposits on Lanai were hurled on shore by a giant tsunami during Pleistocene time (Moore and Moore 1984). The Lanai tsunami may have been triggered by the large-scale Alika submarine landslide off the northwest coast of Hawaii (J. G. Moore et al. 1989). Destruction of sand barrier islands off the southeastern Australian coast also may have been caused by the Lanai tsunami (Young and Bryant 1992). Maximum wave run-up in Australia

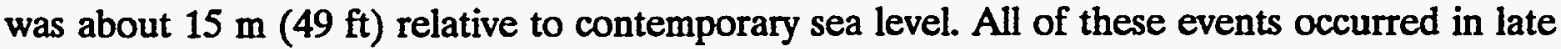
Pleistocene time. Although a combination of storm surge and higher sea levels during Pleistocene time may account for the destruction of sand barrier islands in Australia, they could not have accounted for the high-standing marine sediments on Lanai. The event discussed here would have an extremely long (perhaps 100,000 years) and unpredictable recurrence interval, with resulting catastrophic worldwide impacts.

Individual large-scale landslides may remove as much as half the subaerial part of a volcano and 10 to $20 \%$ of the entire volcanic edifice (Holcomb and Searle 1991). Such large-scale and rapid redistribution of mass might cause the oceanic crust to rebound in response to the shift in load. No rheological modeling has been done to test the hypothesis that high-standing marine sediments may have resulted from local uplift rather than from a giant tsunami.

Giant tsunamis (assuming they exist) are exceedingly rare events. There is no historical record of such events in the Hawaiian Islands. Proposed triggering mechanisms (large-scale submarine landslides) occur on a time scale of about 100,000 years (J. G. Moore et al. 1989).

Excluding Hawaii, there is no historical record of tsunami wave run-up heights that exceed $10 \mathrm{~m}$ (33 ft). Therefore, installations located throughout most of the Hawaiian Islands and sited

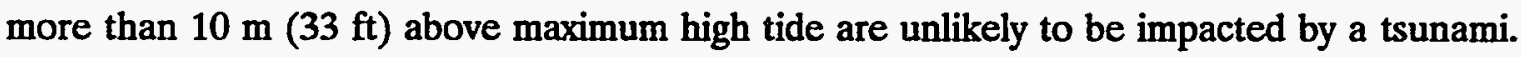
Tsunamis on Hawaii are discussed further in Sect. 3.

\subsection{Earthquakes}

Figure 2 shows the Uniform Building Code (UBC) seismic zone map for the state of Hawaii (ICBO 1991). Major earthquakes are most likely to occur on Hawaii and least likely to occur on Oahu. Hawaii is in seismic zone 3, where major earthquake damage has a $10 \%$ probability of occurrence at least once in 50 years (equivalent to a 500 -year return period) with (PGAs) ranging from 0.2 to $0.4 \mathrm{~g}$. [PGA is a common physical parameter used to measure the amplitude (severity) of ground shaking during an earthquake; $g$ is the gravitational field strength 


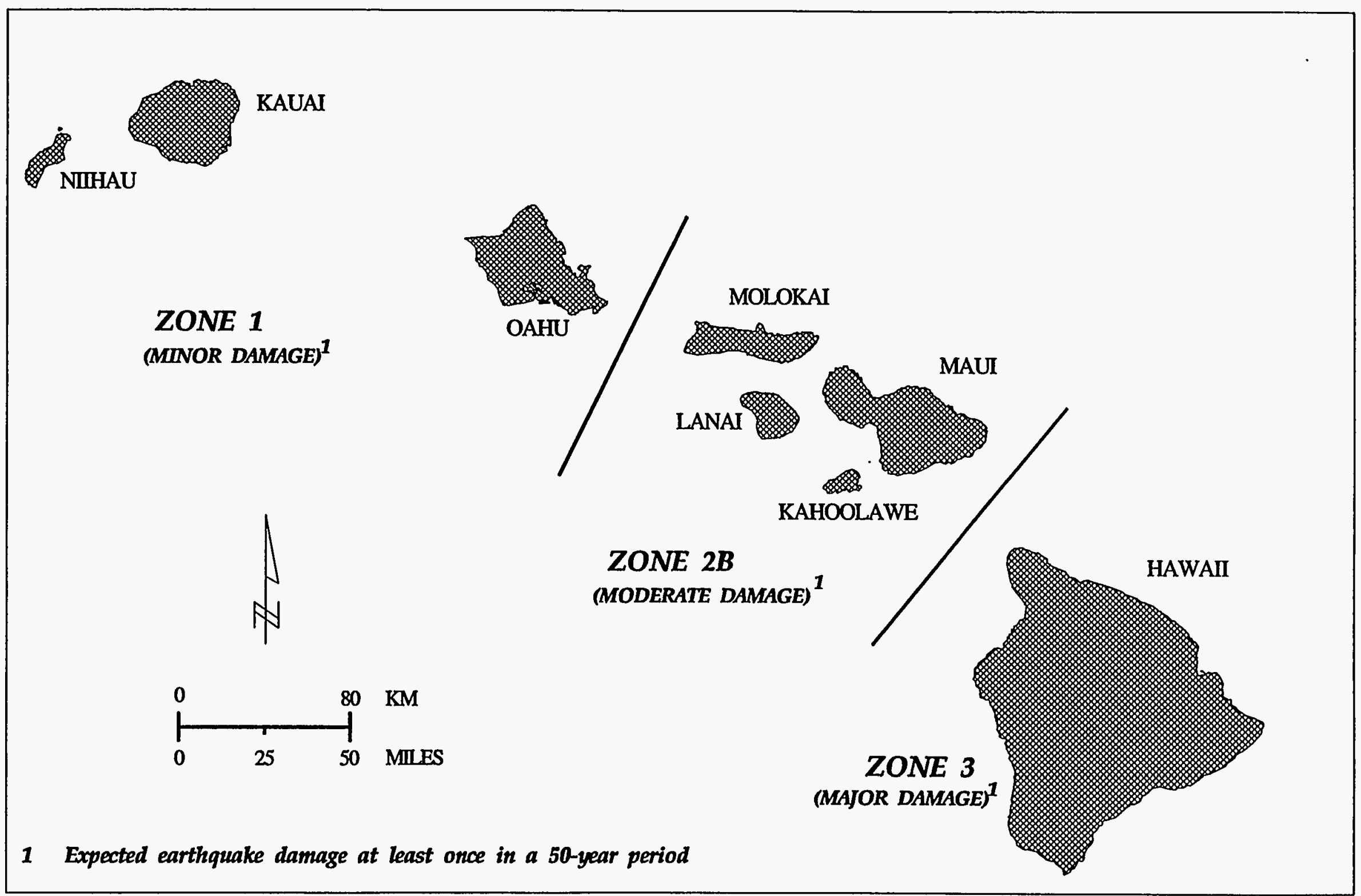

Fig. 2. Uniform Building Code seismic zone map of the State of Hawaii. Source: ICBO 1992. 
on the earth's surface (approximately $980 \mathrm{~cm} / \mathrm{s}^{2}$ ).] Structures that meet UBC recommendations for seismic zone 3 are designed to resist a PGA of $0.3 \mathrm{~g}$. Klein 1994 suggests that the southern third of Hawaii should be placed in seismic zone 4, where great earthquake damage may recur on the order of once every 500 years. Maui and Molokai are in seismic zone 2B, where moderate earthquake damage has a $10 \%$ probability of occurrence in 50 years, with PGAs between 0.1 and $0.2 \mathrm{~g}$. Structures that meet UBC recommendations for seismic zone $2 \mathrm{~B}$ are designed to resist a PGA of $0.2 \mathrm{~g}$. Oahu and Kauai are in seismic zone 1, where minor earthquake damage has a $10 \%$ probability of occurrence in 50 years, with PGAs ranging from 0.05 to $0.1 \mathrm{~g}$. Structures that meet UBC recommendations for seismic zone 1 are designed to resist a PGA of $0.075 \mathrm{~g}$.

Only two historical Hawaiian earthquakes, other than those on Hawaii, caused any reported damage. The only major earthquake not located on Hawaii occurred off the north shore of Maui in 1938. Its Richter magnitude was estimated at 6.7 (Stearns 1966) and caused moderate damage on Maui and Molokai and minor damage on Oahu (Macdonald, Abbott, and Peterson 1983). Another earthquake (located near Oahu) broke windows in Honolulu in 1948. Earthquakes on Hawaii are discussed in Sect. 3.

\subsubsection{Geologic Hazard Zones}

The hazard potential of future lava flows is classified according to the location and ages of lava flows in the past (Mullineaux, Peterson, and Crandell 1987). The southwest rift zone of Haleakala (on east Maui) and the southeastern slope of this rift zone are in lava flow hazard zones 3 and 4, respectively (using lava hazard zones as defined for Hawaii in Sect. 3). All other areas on the south slope of Haleakala are in lava hazard zones 7 through 9 as defined for Hawaii. Historical lava flows (about 1790) on eastern Maui occurred along two vents in the southwest rift zone of Haleakala (lava hazard zone 3) and entered the sea a few kilometers northwest of Cape Hanamanioa.

The lava flow hazard is low throughout Oahu. No lava hazard zones are available for Oahu. Although most volcanic rocks on Oahu are late Pliocene or early Pleistocene (more than one million years old), late Pleistocene volcanic rocks (the Honolulu volcanic series) are present in eastern Oahu. Some rocks in the Honolulu volcanic series may be as young as Holocene, but locations of questionable Holocene lava flows are not available (Langenheim and Clague 1987).

\section{IAAND FEATURES AND SOILS}

Land features and soils are highly dependent on the age of volcanic rocks and microclimates in the Hawaiian Island chain. Generally, lava flows less than 400 years old are only slightly weathered, little or no soil has formed on them, and their surfaces have not been modified by erosion. Soils are generally thin or absent in the rift zones and slopes of Kilauea [from less than 0.1 to $0.3 \mathrm{~m}$ ( 0.3 to $1.0 \mathrm{ft}$ ) thick] (Moore and Trusdell 1991). Soils are similarly thin or absent on the slopes of Mauna Loa. Immature soil horizons have developed on Mauna Kea, and 
mature soil horizons have developed throughout the rest of the Hawaiian Island chain. Generally, dry climate soils that are poor in organics and chemically weathered products form on the lee (i.e., southwest) sides of the islands, and wet climate soils that are rich in organics and chemically weathered products form on the windward (northeast) sides of the islands. Extensive areas of bauxitic soils on the northeast sides of Maui and Hawaii (Macdonald, Abbott, and Peterson 1983) suggest that rainwater has leached most soluble constituents from the soil. Deep gullies and streams also have developed on the slopes of Kohala (especially the windward slopes) and older volcanoes in the Hawaiian Islands.

\section{HAWAII}

The following section describes geologic hazards, land features, and soils on Hawaii. Volcanic activity, regional subsidence, large- and small-scale submarine landslides, tsunamis, and UBC seismic zones on Hawaii have been discussed above in Sect. 2.

\subsection{GEOLOGIC HAZARDS}

\subsubsection{Volcanic Activity}

The most obvious hazard related to volcanic eruptions is the flow of lava. Other kinds of hazards include tephra (volcanic ash), volcanic gas, pyroclastic surge hazards, and surface fissures and subsidence. Figure 3 shows volcanoes and lava hazard zones on Hawaii (Mullineaux, Peterson, and Crandell 1987). Some (but not all) earthquakes also are associated with volcanic activity (Crandell 1987; Heliker 1991). Lava hazard zones range from 1 to 9 (highest to lowest hazard). Table 2 defines levels of hazard in each zone. The lava hazard along the slopes of Mauna Kea and Kohala is very low. These volcanoes are beyond their shield-building stages and have experienced no historic eruptions. The lava hazard on the slopes of Hualalai is low. Although this volcano has erupted historically, it too is beyond its shield-building stage. The lava hazard on the slopes of Mauna Loa and Kilauea is moderate to very high. These two volcanoes are in their active shield-building stages and have erupted repeatedly throughout historic and recent time.

The lava hazard is greatest (lava hazard zone 1) in the summit areas and active rift zones of Mauna Loa and Kilauea. Over 25\% and 65\% of the land area in zone 1 has been covered by lava at least once in the last $\mathbf{2 0 0}$ and $\mathbf{7 5 0}$ years, respectively. Probabilistic estimates for inundation by lava flows are summarized in Sect. 5 .

Although the lava hazard is still high in zone 2, it is somewhat lower than in zone 1. Areas in zone 2 are adjacent to and downslope from active rift zones. Somewhat lower percentages of land areas have been covered by historical and Holocene lava flows than is the case in the active rift zones. 


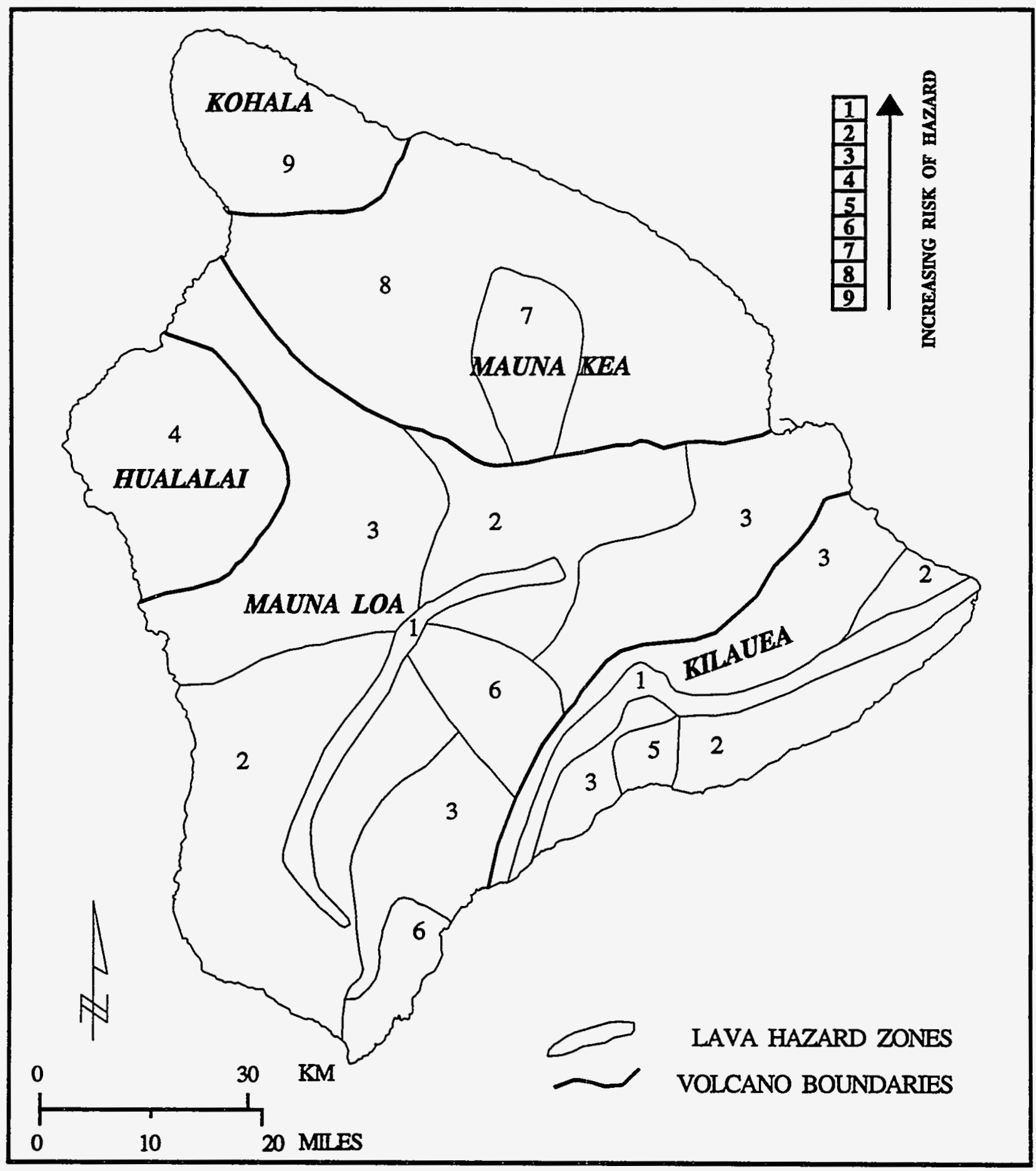

Fig. 3. Volcanoes and lava hazard zones on Hawaii. Soroce: Mullineaux, Peterson, and Crandell 1987. 
Table 2. Hazard zones for lava flows on Hawaii

\begin{tabular}{|c|c|c|c|}
\hline Zone & $\begin{array}{l}\% \text { of area } \\
\text { covered by lava } \\
\text { since } 1800\end{array}$ & $\begin{array}{l}\% \text { of area } \\
\text { covered by lava in } \\
\text { last } 750 \text { years }\end{array}$ & Explanation \\
\hline 1 & $>25$ & $>65$ & $\begin{array}{l}\text { Includes the summits and rift zones } \\
\text { of Kilauea and Mauna Loa where } \\
\text { vents have been repeatedly active in } \\
\text { historic time }\end{array}$ \\
\hline 2 & $15-25$ & $25-75$ & $\begin{array}{l}\text { Areas adjacent to and downslope of } \\
\text { active rift zones }\end{array}$ \\
\hline 3 & $1-5$ & $15-75$ & $\begin{array}{l}\text { Areas gradationally less hazardous } \\
\text { than zone } 2 \text { because of greater } \\
\text { distance from recently active vents } \\
\text { and/or because the topography makes } \\
\text { it less likely that flows will cover } \\
\text { these areas }\end{array}$ \\
\hline 4 & $\sim 5$ & $<15$ & $\begin{array}{l}\text { Includes all of Hualalai, where the } \\
\text { frequency of eruptions is lower than } \\
\text { on Kilauea and Mauna Loa. Flows } \\
\text { typically cover large areas }\end{array}$ \\
\hline 5 & None & $\sim 50$ & $\begin{array}{l}\text { Areas currently protected from lava } \\
\text { flows by the topography of the } \\
\text { volcano }\end{array}$ \\
\hline 6 & None & Very little & Same as zone 5 \\
\hline 7 & None & None & $\begin{array}{l}\text { Twenty percent of this area covered } \\
\text { by lava } 3,500-5,000 \text { years ago }\end{array}$ \\
\hline 8 & None & None & $\begin{array}{l}\text { Only a small portion of this area } \\
\text { covered by lava in the past } 10,000 \\
\text { years }\end{array}$ \\
\hline 9 & None & None & $\begin{array}{l}\text { No eruption in this area for the past } \\
60,000 \text { years }\end{array}$ \\
\hline
\end{tabular}

Source: Heliker 1991. 
The lava hazard in zone 3 is moderate. Only 1 to $5 \%$ of the land in these areas has been covered by lava in the last $\mathbf{2 0 0}$ years. These areas are close to, but upslope from, active rift zones.

The lava hazard in other zones is low to very low. High topographic scarps deflect lava flows away from high-standing areas adjacent to active rift zones. Other areas are neither downslope from nor adjacent to active rift zones, and still others are not close to active shieldbuilding volcanoes.

The hazard zones mapped by Mullineaux, Peterson, and Crandell (1987) for tephra [volcanic ash (tuff), cinders, and climbers] are shown in Fig. 4. Only three tephra hazard zones are recognized. Volcanic gas hazard zones are the same as those for tephra hazards. Prior to eruption, magma contains considerable quantities of dissolved gas (water vapor, carbon dioxide, hydrogen sulfide, and sulfur dioxide are the major constituents). These gases come out of solution as the magma approaches the surface and erupts as lava. Volcanic gases can be carried long distances by the wind. Furthermore, gases called laze are created by reactions between seawater and lava (chiefly sulfuric acid, hydrochloric acid, and water vapor) (Gerlach et al. 1991).

Tephra hazard zone 1 includes the summit areas and rift zones of Kilauea and Mauna Loa and extends $2 \mathrm{~km}$ ( 1.2 miles) beyond these rift zone boundaries. Thick individual tephra falls [10 cm ( 4 in.) or more] and large tephra fragments generally are confined to tephra hazard zone 1.

Mullineaux's tephra hazard zone 2 includes all the slopes of Kilauea, Mauna Loa, and Hualalai. These regions receive frequent but thin deposits of volcanic ash (but no large fragments) from lava fountains along the rift zones and summits of Kilauea and Mauna Loa.

Tephra hazard zone 3 includes the slopes of Mauna Kea and Kohala on the northeast side of Hawaii. Tephra falls are thin in this region due to increased distances from Mauna Loa and Kilauea, and they are infrequent because the prevailing winds blow toward the southwest across Mauna Loa and Kilauea.

Historic pyroclastic surges have only been observed adjacent to Kilauea's caldera (Mullineaux, Peterson, and Crandell 1987). These surges are phreatic explosions related to the interaction between molten rock and groundwater or seawater. The superheated steam escapes forcefully from volcanic vents. Rock fragments of all sizes are carried upward. Satellite volcanoes along the rift zones of Kilauea and Mauna Loa have the potential for phreatic explosions.

Hawaii has been mapped into four small-scale ground failure hazard zones (Fig. 5) (Mullineaux, Peterson, and Crandell 1987). These ground failures include surface fissures and subsidence. Zone 1 includes the summit areas and rift zones of Kilauea and Mauna Loa, where fractures and subsidence occur most frequently. Ground failure hazard zone 2 lies on the south flank of Kilauea. These ground failures occur less frequently along the Koae and Hilina fault zones than within the rift zones. Occasional ground failures also occur along smaller faults of Kilauea's south slope. Ground failure hazard zone 3 is located along the Kaoiki and Kealakekua fault systems on the lower southeastern slope of Mauna Loa and adjacent to the southwest rift zone of Kilauea. Ground failures occur less frequently on Mauna Loa's fault systems than on 


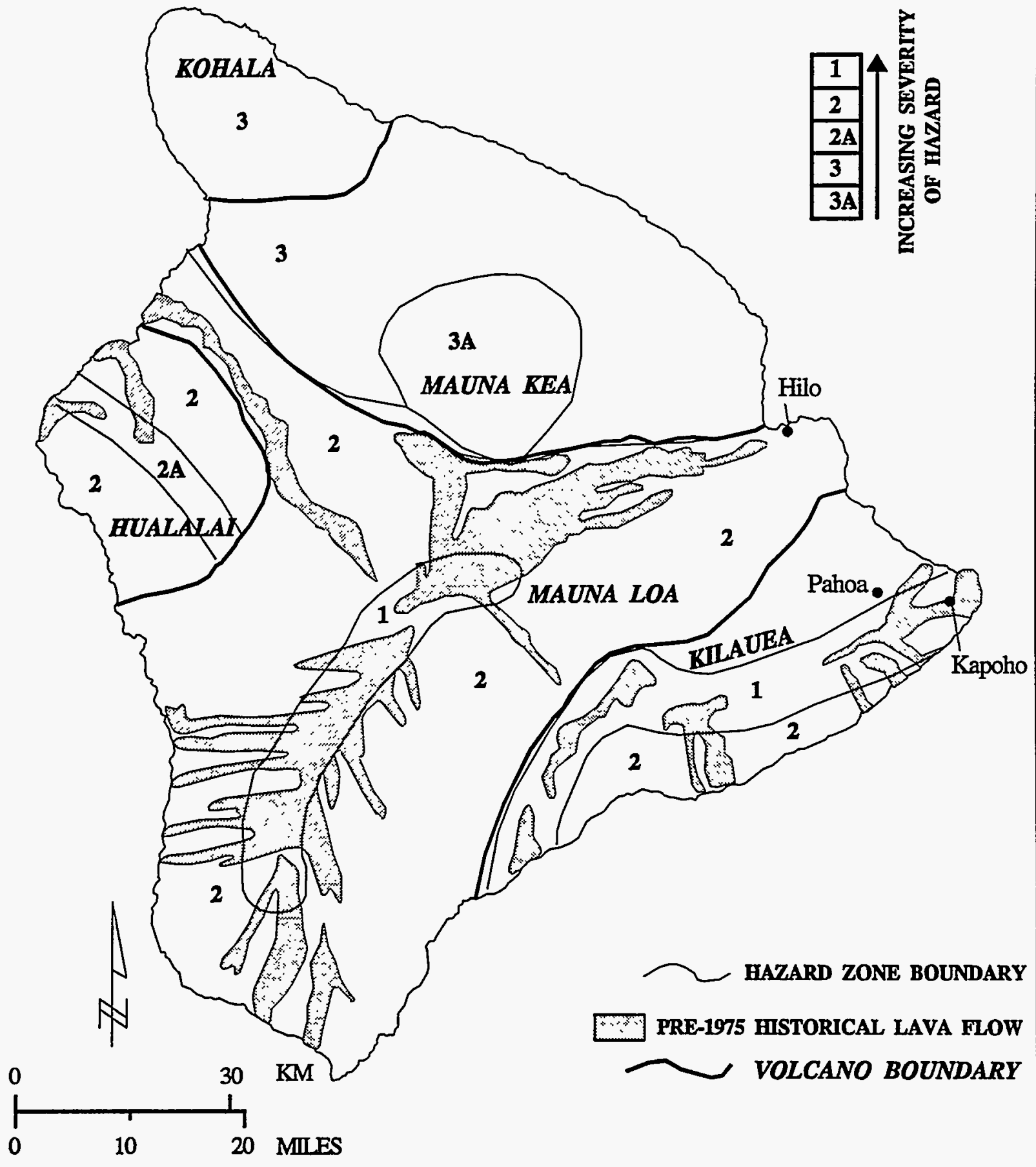

Fig. 4. Tephra (volcanic ash) hazard zones on Hawaii. Source: Mullineaux, Peterson, and Crandell 1987. 


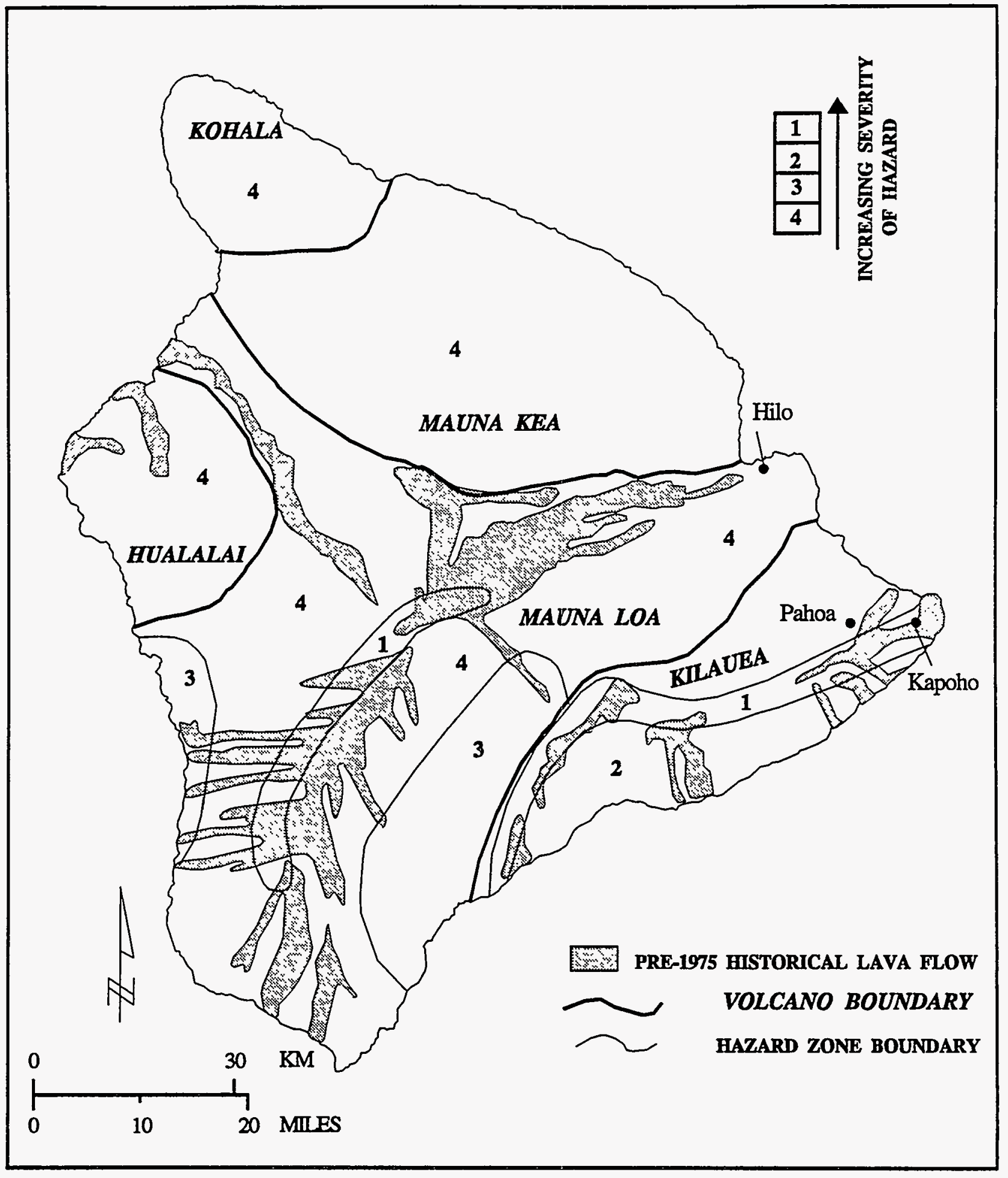

Fig. 5. Ground failure hazard zones on Hawaii. Saure: Mullineaux, Peterson, and Crandell 1987. 
Kilauea's. Ground failure hazard zone 4 includes all other areas of Hawaii. The ground failure hazard in zone 4 is minimal.

\subsubsection{Earthquake and Earthquake-Induced Hazards}

Figure 6 shows the locations of 14 historic strong-motion earthquakes on Hawaii. Most of these earthquakes occurred in sparsely populated areas where little damage was reported. Table 3 provides regions, dates, magnitudes, and depths of focus for these earthquakes. No depths of

Table 3. Historical earthquakes of magnitude $\geq 6$ since 1868 on Hawaii

\begin{tabular}{cllcc}
\hline Year & Date & \multicolumn{1}{c}{ Region } & Magnitude & $\begin{array}{c}\text { Depth } \\
\text { (km) }\end{array}$ \\
\hline 1868 & $3 / 28$ & Mauna Loa south flank & $6.5-7.0$ & No data \\
1868 & $4 / 2$ & Mauna Loa south flank & $7.5-8.1$ & No data \\
1929 & $10 / 5$ & Hualalai & 6.5 & No data \\
1941 & $9 / 25$ & Kaoiki & 6.0 & No data \\
1950 & $5 / 29$ & Mauna Loa southwest rift & 6.2 & No data \\
1951 & $4 / 22$ & Kilauea & 6.3 & 32 \\
1951 & $8 / 21$ & Kona & 6.9 & 8 \\
1952 & $5 / 23$ & Kona & 6.0 & 8 \\
1954 & $3 / 30$ & Kilauea south flank & 6.5 & 8 \\
1962 & $6 / 27$ & Kaoiki & 6.1 & 9 \\
1973 & $4 / 26$ & Honomu & 6.2 & 40 \\
1975 & $11 / 29$ & Kilauea south flank & 7.2 & 9 \\
1983 & $11 / 16$ & Kaoiki & 6.6 & 10 \\
1989 & $6 / 25$ & Kilauea south flank & 6.1 & 14 \\
\hline
\end{tabular}

Source: Heliker 1991.

focus are available for strong-motion earthquakes that occurred before 1950 . Since 1950, the ability to determine magnitude, location, and depth of an earthquake has continuously improved. All but two of the strong-motion earthquakes occurred along the slopes, rift zones, or summits of the active shield-building volcanoes (Kilauea and Mauna Loa). The 1951 earthquake near Kilauea's summit occurred at a depth of about $32 \mathrm{~km}$ (20 miles) and was apparently related to magmatic processes within the earth's mantle. Most of the other earthquakes occurred at shallow 


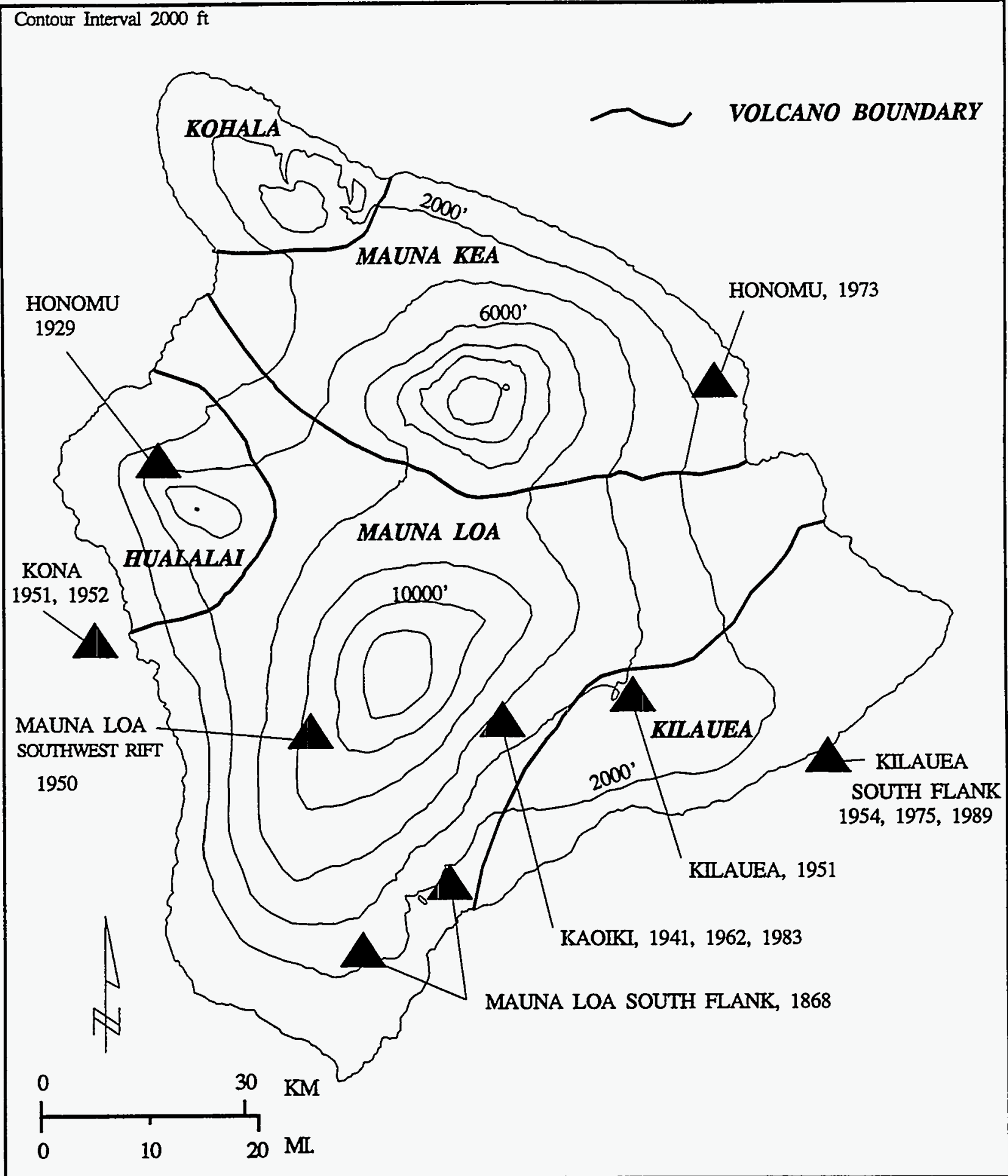

Fig. 6. Historic strong-motion earthquakes on Hawaii. Source: Heliker 1991. 
depths downslope and seaward from the summits of Kilauea and Mauna Loa. These shallow earthquakes are believed to have originated in the pile of volcanic rocks overlying oceanic crust and/or in the ocean floor sediments at the base of the volcanic pile (Crosson and Endo 1981; Bryan 1992; Pelayo and Wiens 1992; Gillard, Wyss, and Nakata 1992). Some of these earthquakes may be associated with large-scale submarine landslides (see Sect. 2.1.3).

Most of Hawaii's earthquakes (including many smaller earthquakes not shown in Fig. 6) are related directly to volcanic activity. They occur before and during eruptions and during noneruptive underground movements of molten rock (magma).

Although all of Hawaii is in UBC seismic zone 3 (ICBO 1991), the summits, rift zones, and seaward slopes of Kilauea and Mauna Loa are areas of significantly higher-than-normal earthquake risk. Seismic hazards on the south flanks and rift zones of Mauna Loa and Kilauea are discussed in Sects. 4 and 5.

There are two general types of ground failure that result from strong-motion earthquakes. One is surface rupture that may take place along an active fault during an earthquake. A second type of ground failure occurs in response to ground shaking caused by shock waves that propagate outward beyond the region of surface rupture.

The most spectacular ground failure is the rapid surface rupture that creates an earthquake along an active fault. Buildings located on active faults cannot be designed to resist such failures. Furthermore, surface ruptures on Hawaii often are close to and parallel to the coastline. The seaward side of the rupture surface generally slides downward and seaward, resulting in land subsidence and possible submergence or exposure to storm surge in the future. Although buildings sited on the seaward side of an active fault may survive the initial ground shaking during an earthquake, they may be damaged or destroyed by flooding. The siting of buildings along an active fault and in coastal areas subject to submergence would not conform with seismic provisions of the UBC.

Ground failure in response to ground shaking is far more common and widespread than surface rupture. Surface rupture accompanies only the largest of earthquakes and occurs only in the epicentral area. In contrast, ground shaking from earthquakes on Hawaii has occasionally caused minor damage on Oahu. If ground shaking is strong enough, it can damage structures sited on otherwise stable ground. Structures sited on thick and unconsolidated materials are at greater risk because the earthquake ground motion is amplified relative to that for structures sited on rock. Structures sited on liquefiable soils (saturated silt and sand bodies along beaches, wetlands, and floodplains) or on steep slopes also are at greater risk of earthquake damage. The earthquake of April 2, 1868, on the south slope of Mauna Loa caused a mudslide which killed 31 people (Tilling et al. 1976). This earthquake also caused a rock fall in Hilo that killed two people. The maximum aerial extent and distance of earthquake-induced landslides on steep slopes as a function of earthquake magnitude suggest that earthquakes similar in size to the 1975 Kalapana event are capable of initiating landslides not only on the south coast but also on unstable ground throughout Hawaii (Keefer 1984). 
As discussed in Sect. 2, tsunamis are often generated by earthquakes. Earthquakes on Hawaii generated two of the largest local tsunami-wave run-up heights in the Hawaiian Islands. The tsunami of April 2, 1868, which occurred in response to the earthquake of the same day (described above), swept over the tops of coconut palms along the southeastern coast of Hawaii, destroyed several villages, and killed 46 people (Lockridge and Smith 1984). The maximum wave run-up height reached $18 \mathrm{~m}(59 \mathrm{ft}$ ) (Wood 1914). The November 29, 1975, earthquake at Kalapana (on the south coast of Hawaii) was accompanied by coastal subsidence up to $3.5 \mathrm{~m}$ $(11.5 \mathrm{ft}$ ) and a tsunami with a wave run-up height that locally exceeded $14 \mathrm{~m}$ (46 ft) (Tilling et al. 1976). Based on the historical record, installations located on Hawaii and sited more than $18 \mathrm{~m}$ ( $59 \mathrm{ft}$ ) above maximum high tide are unlikely to be inundated by a tsunami.

\subsection{LAND FEATURES AND SOILS}

Hawaii is divided into three subregions here for ease of discussion-the northwestern, central, and southeastern subregions, respectively. The southwestern slopes of Kohala volcano are separated from the northeastern slopes by the volcano's northwest rift zone, summit area, and southeast rift zone (Fig. 3). The southwestern slopes have not been dissected by erosion because the volcanic rocks (Hawi volcanic series) are relatively young and the climate is semiarid. Soils and weathered rock are thicker in older volcanic rocks (Pololu volcanic series). The deepest streamcut valleys are less than $30 \mathrm{~m}(98 \mathrm{ft})$ deep, and the slopes are essentially the original landforms constructed by the volcano (Macdonald, Abbott, and Peterson 1983). Erosion and sedimentation potentials on the southwestern slopes of Kohala are not severe.

\subsection{Central Subregion}

The Saddle Road passes through nearly barren lava flows of Pleistocene and Holocene age on the western slopes of Mauna Kea. As this road swings to the east, it is built on historic (i.e., 1881, 1855, and 1935) lava flows from the summit area and northeast rift zone of Mauna Loa (USGS 1986). Soils on these lava flows are thin or absent, and no perennial stream crossings span the saddle area (USDA 1973). Prehistoric Mauna Kea lava flows are located a few kilometers north of the existing Saddle Road. Thin soils have developed on these older lava flows, and some erosion and sedimentation may be expected in disturbed areas on the slopes of Mauna Kea. The lava hazard on Mauna Kea's slopes is slight. Lava tubes (hollow subterranean drainage paths for molten lava) may be present in both Mauna Loa and Mauna Kea lava flows. Such areas provide unstable foundations.

\section{2 .2 Southeastern Subregion}

Most of the southeastern subregion is underlain by lava flows covered by very thin soils. Relatively thick soils are found only in a zone 3 to $6 \mathrm{~km}$ (1.9 to 3.7 miles) wide on the northern 
side of the Puna District, and in areas within 6 to $12 \mathrm{~km}$ ( 3.7 to 7.5 miles) of Hilo (USDA 1973). County Road 11 is underlain by relatively thick soils, and County Roads 13 and 20 also are underlain by thick soils near Hilo. Although the annual average rainfall is high, there is only one significant stream-crossing in this subregion. Evapotranspiration by rich plant life and infiltration through youthful lava flows leaves little excess moisture for runoff. Waiakea Stream flows from springs on the lower east slope of Mauna Loa and enters Hilo Bay from the southwest. Slopes are gentle except near the Saddle Road and in the immediate area of the east rift zone of Kilauea. The presence of unmapped lava tubes in both Mauna Loa and Kilauea lava flows could destabilize foundations.

\section{THE PUNA DISTRICT}

The following section discusses local stratigraphy, structure, subsidence, earthquakes, and locations of historical lava flows in the Puna District of Hawaii.

\subsection{VOLCANIC ERUPTIONS}

Kilauea's east rift zone is about $125 \mathrm{~km}$ (78 miles) long, including the 70-km- (44-mile-) long submarine Puna Ridge (Moore 1992). Most of the discussion that follows relates to the Kilauea's lower east rift zone (LERZ), which is continuous with the middle east rift zone (MERZ) on the southwest and the submarine Puna Ridge on the northeast.

The LERZ is an elongate ridge, 50 to $150 \mathrm{~m}$ (160 to $490 \mathrm{ft}$ ) above the adjacent terrain (Moore 1992). This ridge is about 3 to $4 \mathrm{~km}$ (1.9 to 2.5 miles) wide and extends $23 \mathrm{~km}$ (14 miles) from the Heiheiahulu volcanic vent to Cape Kumukahi at the southeastern tip of Hawaii. The ridge is marked by low spatter ramparts and cinder cones as high as $60 \mathrm{~m}(200 \mathrm{ft})$. The ridge's elevation gently decreases from southwest to northeast and ranges from a high of $522 \mathrm{~m}$ (1713 ft) at Heiheiahula's dormant volcanic vent to sea level at Cape Kumukahi (Fig. 7). Lava generally has flowed downslope, either southeast or northeast, depending on vent location relative to the topographic crest of the LERZ. No volcanic eruptions have occurred in the LERZ since 1961.

Figure 7 shows the locations of historic lava flows and late Holocene volcanic landforms (cinder cones and craters) in the LERZ. It also shows historic lava flows that have flowed beyond the LERZ, covered late Holocene lava flows, and entered the sea several kilometers to the northeast and south. Late Holocene lava flows underlie the entire region shown in the figure.

Although lava tubes are poorly exposed and generally unmapped in the LERZ, many of them are probably concealed beneath a variety of volcanic landforms and vegetation. Wellexposed inactive lava tubes occur in road cuts along the Chain of Craters Road on the south side of Kilauea's summit and upper east rift zone (UERZ) (Cooper and Kauahikaua 1992). Active lava tubes occur in the ongoing Pu'u 'O'o eruptions in the UERZ (Heliker and Wright 1991). 


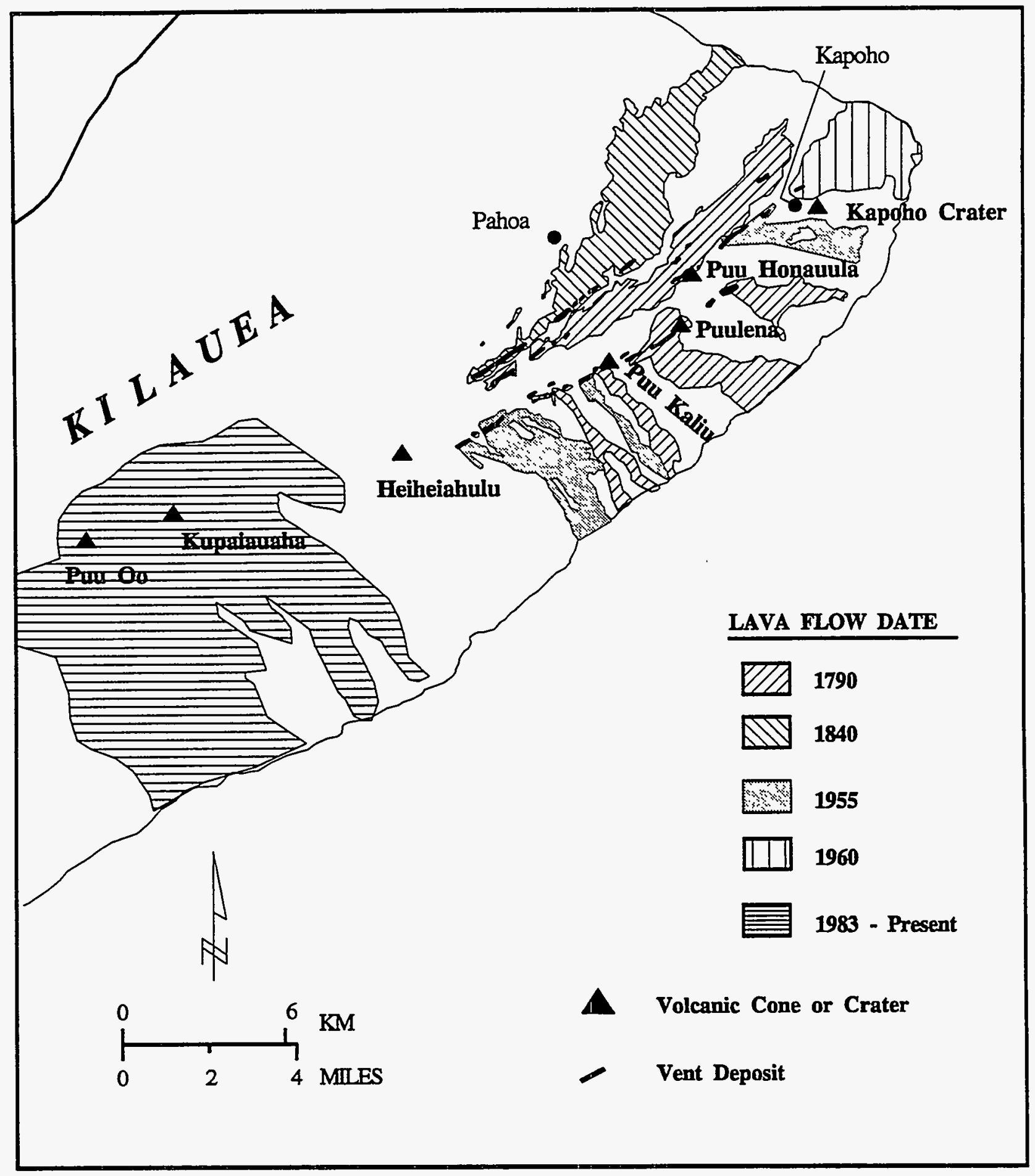

Fig. 7. Volcanic landforms in the lower east rift zone. Source: Moore 1992 
Major eruptions occurred along the LERZ around 1790 and in 1840, 1955, and 1960. A smaller eruption also occurred in 1961. Eruptions produce tephra and lava flows (both a'a and pahoehoe). A'a lava flows are highly viscous (stiff) and slow-moving and have rough surfaces. In contrast, pahoehoe lava flows are highly fluid and have smooth surfaces. It is estimated that at least $25 \%$ of the land area in and adjacent to the LERZ has been covered by tephra and lava flows in historic time (the last 200 years). An additional $70 \%$ of the land area was covered between 200 and 750 years ago, and all of the land area was covered at least once in the past 1500 years (Moore 1992).

At least 112 separate eruptions are estimated to have occurred in the past 2360 years, and the average LERZ-wide dormant interval has been 13.6 years over the past 1500 years. However, the average dormant period from 1790 to 1961 was 43 years. Historic dormant periods vary considerably for the LERZ. Although no eruptions occurred from 1840 to 1955, three eruptions occurred between 1955 and 1961. Probabilistic estimates of inundation by lava flows are summarized in Sect. 5.

More than 150 Holocene and historic lava flows have been mapped in the LERZ (Moore 1983). These flows range in width from 100 to $1000 \mathrm{~m}$ (330 to $3300 \mathrm{ft}$ ); their lengths range up to $18 \mathrm{~km}$ (11 miles) but are typically between 2 and $6 \mathrm{~km}$ (1.2 and 3.7 miles). Their thicknesses range up to $15 \mathrm{~m}$ ( $49 \mathrm{ft}$ ) but are generally between 4 and $8 \mathrm{~m}$ (13 and $26 \mathrm{ft}$ ).

Heiheiahulu is the largest satellite shield volcano in the LERZ and may have developed over a period of several years. Approximately $0.4 \mathrm{~km}^{3}\left(0.09 \mathrm{mile}^{3}\right)$ of lava erupted from Heiheiahulu near the end of the prehistoric period. Moore (1983) states that the prehistoric cones known as Puu Kaliu and Puu Honuaula (400-750 and 200-400 years old, respectively) were constructed through lengthy eruptions that extruded between 0.1 and $0.2 \mathrm{~km}^{3}(0.02$ and $0.05 \mathrm{mile}^{3}$ ) of tephra and lava. The aggregate volume of lava deposited in the LERZ between 1790 and 1983 is about $1.0 \mathrm{~km}^{3}\left(0.2 \mathrm{mile}^{3}\right)$.

Most of the surface vents in the southwest half of the LERZ are located on the southern side of the rift zone (Moore 1983). Older vents in the central and northern parts of the rift zone were buried beneath voluminous lava flows from the Heiheiahulu vent and scattered vents constructed during the 1790 eruptions.

Active lava flows from the vents of Pu'u 'O'o and nearby Kupaianaha (in the UERZ) reach within about $1 \mathrm{~km}$ ( 0.6 mile) of the southwest end of the LERZ. These eruptions far exceed those of Mauna Ulu in both duration and volume and are the largest and longest sustained historical eruptions in Kilauea's rift zones. Episodic eruptions began in 1983 at Pu'u 'O'o, and more sustained eruptions continue to this day at Kupaianaha (Heliker and Wright 1991). These sustained eruptions provide an upper bound for potential future large and sustained eruptions in the LERZ. Between 1983 and 1991, lava flows from Pu'u 'O'o and Kupaianaha covered $75 \mathrm{~km}^{2}\left(29 \mathrm{mile}^{2}\right)$ to depths ranging up to $25 \mathrm{~m}(82 \mathrm{ft})$. These flows devastated downslope communities in the Kalapana region on the south coast of Hawaii.

Over the first 3 years of activity at Pu'u 'O'O, 44 episodes of high fountaining [up to $300 \mathrm{~m}$ (980 ft) in height] built a steep-sided cinder and spatter cone $255 \mathrm{~m}$ (836 ft) high and 
covered $42 \mathrm{~km}^{2}$ (16 mile ${ }^{2}$ ) with a'a lava. Large quantities of volcanic gases (called vog) were vented to the atmosphere during such high-fountaining events. In July 1986, the vertical conduit of Pu'u 'O'o ruptured, and magma erupted through new fissures at the base of the cone. Two days later, another fissure extended $3 \mathrm{~km}$ (1.9 miles) downrift to form the Kupaianaha vent, which has been active ever since. This event marked the end of high fountaining and the beginning of continuous eruption of lava (Heliker and Wright 1991).

A lava pond developed over the Kupaianaha vent. Overflows from the pond constructed a gently sloped satellite shield volcano, which reached a height of $55 \mathrm{~m}(180 \mathrm{ft})$ in less than one year. By November 1986, a lava tube had formed between the pond and the ocean, $12 \mathrm{~km}$ (7.5 miles) to the south. Lava flows from Kupaianaha have entered the ocean intermittently since this time, giving rise to an atmospheric steam plume (laze) enriched in hydrochloric acid. This plume is hazardous to downwind communities. After eruptions shifted to Kupaianaha, the Pu'u 'O'o cinder cone gradually collapsed to form a 250-m- (820-ft-) wide crater with an intermittently active lava pond at its bottom (Heliker and Wright 1991).

The collapse of volcanic cones to form two of the largest craters in the LERZ (Puulena and Kapoho) were accompanied (and perhaps enlarged) by phreatic explosions (Moore 1983). These two craters formed between 200 and 750 years ago and are more than $1 \mathrm{~km}(0.6$ mile) across. A thin veneer of tuff locally covers older lava flows for a distance of $1 \mathrm{~km}(0.6 \mathrm{mile})$ surrounding Kapoho crater, which lies only $20 \mathrm{~m}$ (66 ft) above sea level. Presumably, ascending magma interacted with seawater to produce violent steam explosions and tuff. Brief steam explosions occurred only $800 \mathrm{~m}$ (2625 ft) from Kapoho crater during an eruption in 1960. Evidence of steam explosions also is present at Puulena and two adjacent, smaller craters. Although seawater is too far beneath Puulena to be the steam source, shallow groundwater may be present.

Long-term secondary magma chambers may underlie the Puulena-Puu Honuaula, Kaliu, and Heiheiahulu areas (Moore 1983). As evidence, Moore cites several eruptions of differentiated tholeiitic basalt during the last 1300 years, recurrent historic shallow earthquake swarms, and a small steam eruption near Puulena in 1955. The occurrence of several small, active fumaroles near Puulena suggests that the heat sources are relatively shallow.

\subsection{RAPID SURFACE DEFORMATION ALONG ACTIVE FAULTS DURING EARTHQUAKES}

Late Holocene faults, currently active faults, and fissures are ubiquitous in the LERZ, as shown in Fig. 8 (Moore 1992). Both the Kapoho and Koae faults have ruptured during earthquakes in historic time (Richter et al. 1970). These surface ruptures and their accompanying earthquake swarms are caused by movement of magma into the rift zone from beneath Kilauea.

Seismicity in the rift zones of Kilauea is largely confined to shallow depth [0-5 km (0-3.1 miles) deep] (Klein and Koyanagi 1985). Furthermore, seismic activity in the LERZ is 


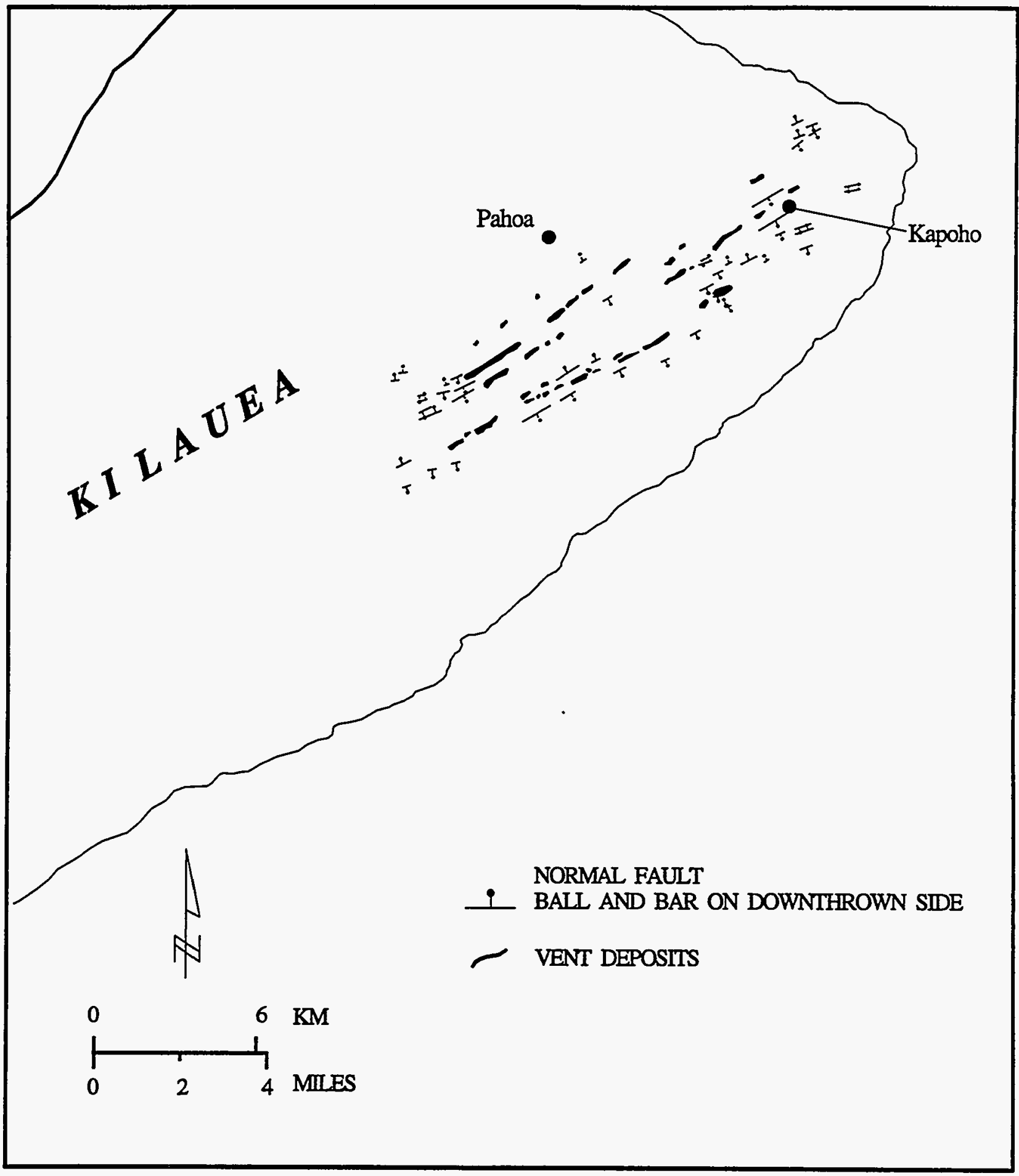

Fig. 8. Faults in the lower east rift mone. Saurce: Moore 1992. 
significantly lower than that of the UERZ, the southwest rift zone, and the summit area of Kilauea.

Historical earthquakes in the LERZ were not strong enough to be felt throughout Hawaii. Based on data in Wyss and Koyanagi (1992), there are no isoseismal maps for any historical earthquakes in the LERZ. The maximum expected magnitude in the LERZ is about 5.

Surface ruptures and earthquakes in the LERZ are not necessarily followed by surface eruption of lava. The Kapoho fault ruptured the surface three times in the twentieth century. This fault first reactivated in 1924 with a maximum displacement of $3.7 \mathrm{~m} \mathrm{(12} \mathrm{ft),} \mathrm{but} \mathrm{no} \mathrm{lava} \mathrm{reached}$ the surface (Macdonald and Eaton 1964). Minor displacements occurred again immediately preceding the large-scale 1955 eruption that threatened the western edge of the town of Kapoho.

On January 13, 1960, episodic surface displacements and earthquakes occurred along a 1-km- (0.6-mile-) wide graben (a down-dropped region between two faults) between the Kapoho and Koae faults (Richter et al. 1970). Cumulative subsidence within the graben reached a maximum of more than $1 \mathrm{~m}(3.5-4 \mathrm{ft})$, and the cumulative rupture surface extended for a distance of $3 \mathrm{~km}$ ( 1.9 miles). During the next two months, lava from the LERZ eruption of 1960 gradually destroyed the town of Kapoho.

Major fault zones with large displacements are nearly all located west of the LERZ, as shown in Fig. 9 (Lipman et al. 1985). The Hilina and Koae fault systems (unrelated to the Koae fault in the LERZ) lie along the south flank of Kilauea, and the Kaoiki fault system lies between Mauna Loa and the southwest rift zone of Kilauea. Occasional historical surface ruptures along these faults produced strong-motion earthquakes that were felt throughout the Hawaiian Islands. The two largest earthquakes, with surface wave magnitudes greater than 7, occurred on the south coast of Hawaii in April 1868 and on November 29, 1975, southwestward from Kalapana for a distance of $30 \mathrm{~km}$ (19 miles). The next two largest events, with surface wave magnitudes between 6 and 7, occurred along the west coast of Hawaii in the Kona District (Wyss and Koyanagi 1992).

Surface deformation associated with the 1975 Kalapana and 1989 south flank earthquakes resulted in surface ground breakage occurring along a 25-km- (16-mile-) long segment of the Hilina fault system during the Kalapana earthquake, with vertical displacements of as much as

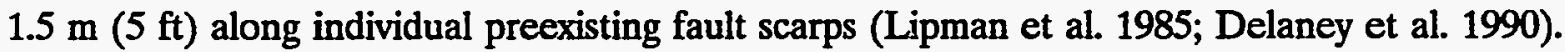
The entire edifice of Kilauea and adjacent lower slopes of Mauna Loa were displaced downward and seaward. Maximum vertical and horizontal displacements were about 8.0 and $3.5 \mathrm{~m}$ (26 and $11 \mathrm{ft}$ ) downward and seaward, respectively. Concurrently, Kilauea's rift zones subsided an

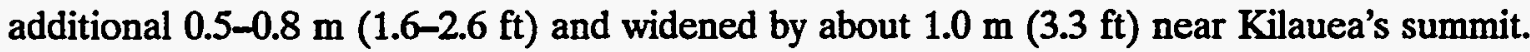
Ground surfaces at Malama $\mathrm{Ki}$ and at Kapoho [10 $\mathrm{km}$ (6 miles) further east in the LERZ] subsided 0.38 and $0.18 \mathrm{~m}$ (1.2 and $0.6 \mathrm{ft}$ ), respectively, during the Kalapana earthquake. The LERZ subsided an additional $0.23 \mathrm{~m}(0.8 \mathrm{ft})$ during the south flank earthquake of June 25, 1989.

These major fault zones are tectonic in origin. Surface ruptures along the Hilina fault system are the result of seaward slumping of the gravitationally unstable and unbuttressed south side of Kilauea's volcanic edifice. Intrusion of magma into the rift zones shoves the slump blocks seaward on a thin layer of weak seafloor sediments at the base of the edifice, as described in 


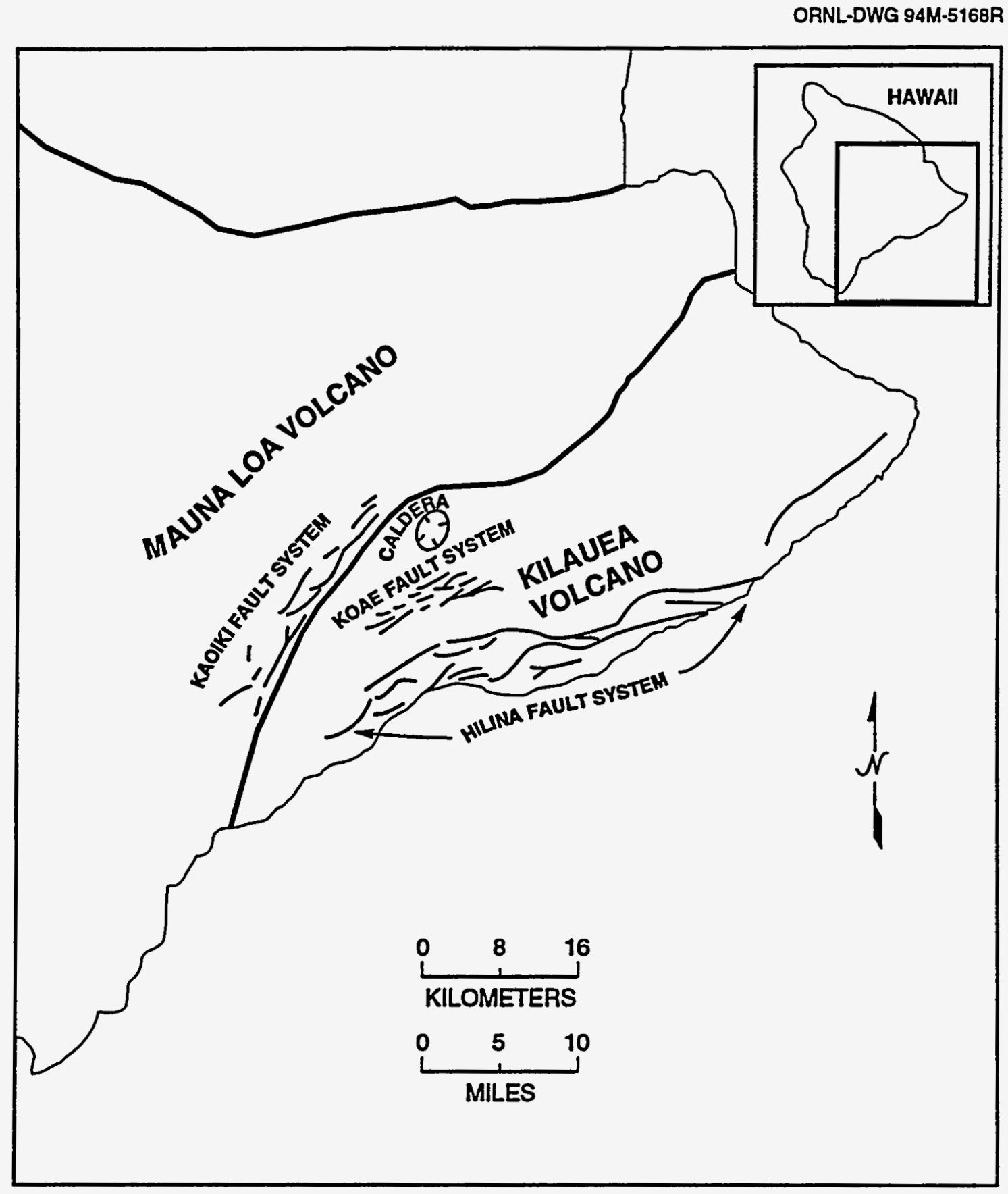

Fig. 9. Fault zones on the south flanks of Mauna Loa and Kilauea. Source: Lipman et al. 1985. 
Sect. 2.1. The toe of the slump block bulges and flares out across the seafloor, creating a tsunami. This process generates intermediate-depth strong-motion earthquakes [between 5 and $13 \mathrm{~km}$ ( 3 and 8 miles) deep]. Data in Klein and Koyanagi (1985) demonstrate that most of the intermediate-depth earthquakes between 1968 and 1981 were on the seaward sides of the UERZ and MERZ of Kilauea. Seismic activity on the seaward side of the LERZ was comparatively low during this time.

\subsection{LONG-TERM SURFACE DEFORMATION}

Kilauea's rift zones have been gradually subsiding and widening since the 1975 Kalapana earthquake. According to Delaney et al. (1990), subsidence was greatest in the rift zones adjacent to Kilauea's summit and gradually decreased from the UERZ to the LERZ. Near Mauna Ulu, the

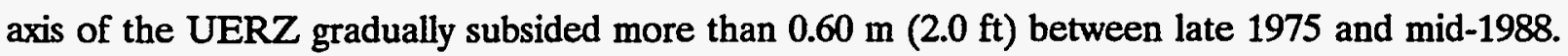
In the same time interval, the LERZ gradually subsided by about $0.15 \mathrm{~m}(0.5 \mathrm{ft})$. Adjacent regions north and south of the LERZ were gradually uplifted by 0.05 and $0.12 \mathrm{~m}(0.2$ and $0.4 \mathrm{ft})$, respectively. Annual subsidence rates at Malama $\mathrm{Ki}$ and Kapoho [10 km (6 miles) further east] were $2.0 \pm 0.3 \mathrm{~cm} /$ year $(0.8 \pm 0.1 \mathrm{in}$./year $)$ and $1.7 \pm 0.4 \mathrm{~cm} /$ year $(0.7 \pm 0.2 \mathrm{in}$./year $)$, respectively. Annual widening of the LERZ near Malama $\mathrm{Ki}$ was $1.5 \pm 0.3 \mathrm{~cm} /$ year $(0.6 \pm 0.1 \mathrm{in}$./year $)$.

Although surface subsidence and widening rates are not large in the LERZ, they are evidence of persistent deformation in response to volcanic and tectonic processes in the region. Furthermore, both long-term and sudden deformation are of sufficient magnitude that they need to be considered in the design of various facilities.

\subsection{EARTHQUAKE PROBABILTIES IN THE PUNA DISTRICT AND ADJACENT REGIONS}

Conditional probabilities of exceedance per 10- to 50-year intervals for strong motion earthquakes in the Hawaiian archipelago and the southern part of Hawaii are provided in Table 4 (Wyss and Koyanagi 1992). These probabilities suggest recurrence intervals of about 15 and 60 years for surface wave magnitudes exceeding 6.0 and 7.0, respectively, on the south side of Hawaii. Earthquake probabilities for the entire Hawaiian archipelago are only a little higher, suggesting that nearly all strong-motion earthquakes occur on the south side of Hawaii. Probabilistic ground motion estimates are provided in Sect. 5.

The LERZ has been at least one order of magnitude less seismically active than Kilauea as a whole during the interval from 1960 to 1980 (Klein and Koyanagi 1985; Koyanagi 1981). Earthquakes of a given magnitude occurred about one-tenth as often for the LERZ from 1962 to 1975, prior to the Kalapana earthquake. The earthquake map of south Hawaii for 1968 to 1981 is consistent with the earlier data.

In summary, Kalapana-sized earthquakes (surface magnitude greater than 7) and associated deformation have recurrence intervals on the order of 100 years on the south flank of 
Table 4. Conditional probability estimates for earthquakes in the Hawaiian archipelago and in the southern parts of the island of Hawaii, 1990-2040

\begin{tabular}{lccc}
\hline $\begin{array}{l}\text { Earthquake } \\
\text { magnitude } \\
(\mathrm{M}) / \text { intensity (I) }\end{array}$ & $1990-2000$ & $1990-2010$ & $1990-2040$ \\
\hline $\mathrm{M} \geq 6$ & $0.84(0.71)$ & $0.97(0.92)$ & $0.999(0.998)$ \\
$\mathrm{M} \geq 6.5$ & $0.50(0.39)$ & $0.75(0.63)$ & $0.97(0.92)$ \\
$\mathrm{M} \geq 7$ & $0.17(0.17)$ & $0.31(0.31)$ & $0.61(0.61)$ \\
$\mathrm{I}_{\max } \geq \mathrm{VII}$ & $0.67(0.63)$ & $0.89(0.86)$ & $0.997(0.99)$ \\
$\mathrm{I}_{\max } \geq \mathrm{VIII}$ & $0.50(0.39)$ & $0.75(0.63)$ & $0.97(0.92)$ \\
\hline
\end{tabular}

Note: Parentheses enclose estimates for southern parts of the island of Hawaii.

Source: Wyss and Koyanagi 1992.

Kilauea (Klein 1994). Such earthquakes also may be accompanied by $20-30 \mathrm{~cm}$ (8-12 in.) of subsidence and moderately large PGAs in the LERZ as described in Sect. 4.2.

More than $2 \mathrm{~m}$ of vertical displacement are possible along reactivated local faults in the LERZ (Kauahikaua, Moore, and Delaney 1994). Such displacements would be accompanied by earthquake swarms with surface magnitudes ranging up to about 5 and may also be accompanied by eruption of lava at the surface. The Kapoho fault has reactivated three times in the $1900 \mathrm{~s}$, twice being followed by sustained lava eruptions. Such events are capable of generating localized destruction of facilities constructed in the LERZ.

\section{SUMMARY OF PROBABILISTIC ESTIMATES FOR TECTONIC ACTIVITY IN THE HAWAIIAN ISLANDS}

Probabilities of inundation during a 50-year time interval in the Puna District of Hawaii (Kauahikaua, Moore, and Delaney 1994) are shown in Table 5. These estimates are based on the historical records of lava flows along the rift zones and flanks of Kilauea and Mauna Loa. Uncertainties are large because only five lava flows occurred in Kilauea's LERZ during the 200-year historical record. Intervals between events ranged from 1 to 115 years. Somewhat less uncertainty is associated with the larger number of historical lava flows along the north and east flanks of Mauna Loa. Both the MERZ and the LERZ have more than a 70\% probability of at least partial inundation by a lava flow in Kilauea's east rift zone in a 50-year interval and have zero probability of inundation by Mauna Loa lava flows. There is a $94 \%$ probability that at least 
Table 5. Probabilities of inundation during a 50-year time interval by lava along the MERZ and LERZ of Kilauea and along various slopes outside rift zones of Kilauea and Mauna Loa

\begin{tabular}{llcc}
\hline & \multicolumn{2}{c}{ Probability of inundation in 50 years (\%) } \\
\cline { 2 - 4 } Location of facility & Kilauea & Mauna Loa & Combined \\
\hline Rift zone location & & & \\
MERZ and LERZ & $70^{a}$ & N/A & N/A \\
MERZ and LERZ & $94^{a}$ & N/A & N/A \\
$\begin{array}{l}\text { Volcano slope location } \\
\text { Inland eastern and Mauna Loa }\end{array}$ & 33 & & $>86^{b}$ \\
$\quad \begin{array}{l}\text { Saddle Road } \\
\text { Coastal eastern and Mauna } \\
\text { Loa Saddle Road }\end{array}$ & 28 & 63 & $>63^{b}$ \\
$\begin{array}{c}\text { Coastal eastern slope and } \\
\text { Mauna Kea slopes }\end{array}$ & 28 & 28 & $>28^{b}$ \\
\hline
\end{tabular}

${ }^{\circ}$ Excluding areas of on-going volcanic activity (Pu'u O'o).

${ }^{b}$ Not determined but greater than for Mauna Loa's slopes alone.

Source: Kauahikaua, Moore, and Delaney 1994.

one area in either the MERZ or the LERZ will be inundated by lava from a Kilauea eruption in a 50-year time interval.

Table 5 also provides probabilities of inundation during a 50-year time interval along selected volcano slopes outside active rift zones. The probability of lava inundation along the east flank of Kilauea is relatively low (28\%-33\%) and similar within the bounds of uncertainty. The eastern and northern slopes of Mauna Loa have larger probabilities of inundation (86\% and $63 \%$, respectively). In contrast, the lower slopes of Mauna Kea, which has been inactive throughout historic time, have almost no probability of lava inundation.

Estimated PGA probabilities as a function of time-interval for selected sites on the south side of Hawaii (Klein 1994) are shown in Table 6. PGAs ranging from 0.2 to $0.4 \mathrm{~g}$ are sufficient to produce major damage in an area, depending on the quality of construction and the type of foundation (unconsolidated volcanic ash or volcanic rock). PGAs near $0.7 \mathrm{~g}$ would cause more widespread damage, including the collapse of poorly constructed and unreinforced masonry structures on unconsolidated soils as well as damage to but no collapse of structures located on firm rock and designed to resist ground shaking caused by earthquakes. PGAs approaching $1.0 \mathrm{~g}$ would probably result in near total destruction regardless of location and seismic design. Data in 
Table 6. Peak ground accelerations $(g)$ with $10 \%$ probability of being exceeded for various time intervals and locations on the south side of Hawaii

\begin{tabular}{lccc}
\hline Location & 10 years $^{\mathrm{a}}$ & 50 years $^{\mathrm{a}}$ & 100 years $^{\mathrm{a}}$ \\
\hline Hilo & 0.3 & 0.4 & 0.5 \\
LERZ & 0.5 to 0.6 & 0.8 to 0.9 & 0.9 to 1.1 \\
South coast & $>0.7$ & $>1.0$ & $>1.2$ \\
\hline
\end{tabular}

Multiply by 10 to obtain approximate return period.

birectly south of Kilauea caldera.

Source: Klein 1994.

Table 6 suggest that Hilo has about a 10\% probability of experiencing major earthquake damage in a 10-year interval. More widespread damage would occur in the LERZ in a similar time frame (assuming similar construction and foundation conditions). In a 10-year period there is about a $10 \%$ probability of significant damage to seismically resistant structures in the LERZ (even some well-built structures may collapse).

Magnitude 8 earthquakes are capable of triggering small submarine landslides in the Hawaiian Islands (Klein 1994). Such earthquakes have a recurrence interval between 100 and 200 years near the south coast of Hawaii but much longer recurrence intervals in other parts of the Hawaiian Islands. Therefore, small earthquake-induced submarine landslides may be expected on the order of once every $\mathbf{1 0 0}$ to 200 years. Although earthquakes are believed to be a major cause of small submarine landslides, storm surge in the form of high surf or mudflows originating on land (Sect. 2) are also known to cause such slides. Storm-induced submarine landslides are not considered in this review. The recurrence interval of small submarine landslides from all sources would be less than once in 100 to 200 years.

Only the largest magnitude 8 earthquakes appear to be associated with prodigious submarine landslides (Klein 1994). Klein suggests that these very large earthquakes and their associated submarine landslides recur at intervals between 100 and 1000 times as long as the smallest magnitude 8 earthquakes. Therefore, the recurrence interval for prodigious submarine landslides in the Hawaiian Islands may range between 10,000 and 200,000 years. This estimate is consistent with the discussion of submarine landslides provided in Sect. 2.

\section{REFERENCES}

Bryan, C. J. 1992. "A Possible Triggering Mechanism for Large Hawaiian Earthquakes Derived from Analysis of the 26 June 1989 Kilauea South Flank Sequence," Bulletin of the Seismological Society of America 82(6), 2368-90. 
Clague, D. A, and G. B. Dalrymple. 1987. "The Hawaiian-Emperor Volcanic Chain," pp. 5-84 in Volcanism in Hawaii, ed. R. W. Decker, T. L. Wright, and P. H. Stauffer, Vol. 1, U.S. Geological Survey Professional Paper 1350, Washington, D.C.

Clague, D. A., J. G. Moore, M. Torresan, and P. Lipman. 1988. "Shipboard Report for Hawaii GLORIA Ground-Truth Cruise F2-88-HW, 25 Feb-9 March, 1988," U.S. Geological Survey Open-File Report 88-292, Washington, D.C.

Cooper, K. M., and J. P. Kauahikaua. 1992. Morphology of Extinct Lava Tubes and the Implications for Tube Evolution, Chain of Craters Road, Hawaii Volcanoes National Park, Hawaii, U.S. Geological Survey Open-File Report 92-352, Hawaiian Volcano Obervatory, Hawaii Volcanoes National Park, Hawaii.

Cox, D. C., and J. F. Mink. 1963. "The Tsunami of 23 May 1960 in the Hawaiian Islands," Bulletin of the Seismological Society of America 53, 1191-1209.

Crosson, R. S., and E. T. Endo. 1981. "Focal Mechanisms of Earthquakes Related to the 29 November 1975 Kalapana, Hawaii Earthquake: The Effect of Structure Models, "Bulletin of the Seismological Society of America 71(3), 713-29.

Delaney, P. T. 1992. "Volcanoes: You Can Pile It Only So High," Nature 357, 194-96.

Delaney, P. T., R. S. Fiske, A. Miklius, A. T. Okamura, and M. K. Sako. 1990. "Deep Magma Body Beneath the Summit and Rift Zones of Kilauea Volcano, Hawaii," Science 247, 1311-16.

Dengler, A. T., E. K. Noda, P. Wilde, and W. R. Normark. 1984. "Slumping and Related Turbidity Currents Along Proposed OTEC Cold-water-pipe Route Resulting from Hurricane Iwa," pp. 475-80 in Proceedings of 1984 Offshore Technology Conference, OTC 4702.

Dengler, A. T., P. Wilde, E. K. Noda, and W. R. Normark. 1984. "Turbidity Currents Generated by Hurricane Iwa," Geo-Marine Letters 4, 5-11.

Dziewonski, A., R. Wilkens, and J. Firth. 1992. Proceedings, Ocean Drilling Program, Initial Report 136, Ocean Drilling Program, College Station, Tex.

Fornari, D. J., and J. F. Campbell. 1987. "Submarine Topography Around the Hawaiian Islands," pp. 109-124 in Volcanism in Hawaï, ed., R. W. Decker, T. L. Wright, and P. H. Stauffer, Vol. 2, U.S. Geological Survey Professional Paper 1350, Washington, D.C. 
Gerlach, T. M., et al. 1991. "Generation of hydrochloric acid by the interaction of seawater and molten lava: the making of laze," in Seminar on vag and laze, Center for the Study of Active Volcanoes, University of Hawaii at Hilo, Hilo.

Gillard, D., M. Wyss, and J. S. Nakata. 1992. "A Seismotectonic Model for Western Hawaii Based on Stress Tensor Inversion from Fault Plane Solutions," Journal of Geophysical Research 97(B5), 6629-41.

Heezen, B. C., and M. Ewing. 1952. "Turbidity Currents and Submarine Slumps, and the 1929 Grand Banks Earthquake," American Joumal of Science 250, 849-73.

Heliker, C. 1991. Volcanic and Seismic Hazards on the Island of Hawaï, U.S. Geological Survey General Interest Publication, Washington, D.C.

Heliker, C., and T. L. Wright. 1991. "The Pu'u 'O'o-Kupaianaha Eruption of Kilauea," EOS, Transactions, American Geophysical Union, 72(47), 521-30 (November 19).

Holcomb, R. T., and R. C. Searle. 1991. "Large Landslides from Oceanic Volcanoes," Marine Geotechnology, 10, 19-32.

ICBO (International Conference of Building Officials). 1991. Uniform Building Code, Whittier, Calif.

Kauahikaua, J., R. B. Moore, and P. Delaney. 1994. "Volcanic Activity and Ground Deformation Hazard Analysis for the Hawaii Geothermal Project Environmental Impact Statement," U.S. Geological Survey Open-File Report 94-553, Menlo Park, Calif.

Keefer, D. K. 1984. "Landslides Caused by Earthquakes," Geological Society of America Bulletin 95, 406-21.

Klein, F. W. 1994. "Seismic Hazards at Kilauea and Mauna Loa Volcanoes, Hawaii," U.S. Geological Survey Open-File Report 94-216, Menlo Park, Calif., in press.

Klein, F. W., and R. Y. Koyanagi. 1985. "Earthquake Map of South Hawaii, 1968-1981," U.S. Geological Survey Miscellaneous Investigations Map I-1611, Washington, D.C.

Koyonagi, R. Y. 1981. "Seismicity of the Lower East Rift Zone of Kilauea Volcano, Hawaii, 1960 to 1980," U.S. Geological Survey Open-File Report 81-984, Menlo Park, Calif. 
Krause, D. C., W. C. White, D. J. W. Piper, and B. C. Heezen. 1970. "Turbidity Currents and Cable Breaks in the Western New Britain Trench," Geological Society of America Bulletin 81, 2153-60.

Lander, J. F., and P. A Lockridge. 1989. United States Tsunamis (including United States possesssions), 1690-1988, U.S. Department of Commerce, National Environmental Satellite Data and Information Service, National Geophysical Data Center, Boulder, Colo.

Langenheim, V. A. M., and D. A. Clague. 1987. "Stratigraphic Framework of Volcanic Rocks of the Hawaiian Islands," pp. 55-84 in Volcanism in Hawaii, R. W. Decker, T. L. Wright, and P. H. Stauffer, eds., Vol. 2, U.S. Geological Survey Professional Paper 1350, Washington, D.C.

Lipman, P. W., J. P. Lockwood, R. T. Okamura, D. A. Swanson, and K. M. Yamashita. 1985. "Ground Deformation Associated with the 1975 Magnitude-7.2 Earthquake and Resulting Changes in Activity of Kilauea Volcano, Hawaii," U.S. Geological Survey Professional Paper 1276, Washington, D.C.

Lockridge, P. A, and R. H. Smith. 1984. Tsunamis in the Pacific Basin, 1900-1983, National Geophysical Data Center, National Oceanic and Atmospheric Administration, Boulder, Colo.

Macdonald, G. A., A. T. Abbott, and F. L. Peterson. 1983. Volcanoes in the Sea, University of Hawaii Press, Honolulu.

Macdonald, G. A., and J. P. Eaton. 1964. "Hawaiian Volcanoes During 1955," U.S. Geological Survey Bulletin 1171, U.S. Government Printing Office, Washington, D.C.

Mark, R. K, and J. G. Moore. 1987. "Slopes of the Hawaiian Ridge," in Volcanism in Hawaii, ed., R. W. Decker, T. L. Wright, and P. H. Stauffer, Vol. U.S. Geological Survey Professional Paper 1350, U.S. Government Printing Office, Washington, D.C.

Moore, J. G., and D. A. Clague. 1992. "Volcano Growth and Evolution of the Island of Hawaii," Geological Society of America Bulletin, 104, 1471-84.

Moore, J. G., D. A. Clague, R. T. Holcomb, P. W. Lipman, W. R. Normark, and M. E. Torreson. 1989. "Prodigious Submarine Landslides on the Hawaiian Ridge," Journal of Geophysical Research 94(B12), 17465-84. 
Moore, J. G., and G. W. Moore. 1984. "Deposit from a Giant Wave on the Island of Lanai, Hawaii," Science 226, 1313-15.

Moore, J. G., W. R. Normark, and C. E. Gutmacher. 1992. "Major Landslides on the Submarine Flanks of Mauna Loa Volcano," Landslide News (6), 13-16.

Moore, J. G., W. R. Normark, and R. T. Holcomb. 1994. "Giant Hawaiian Underwater Landslides," Science 264.

Moore, R. B. 1983. "Distribution of Differentiated Tholeitic Basalts on the Lower East Rift Zone of Kilauea Volcano, Hawaii: A Possible Guide to Geothermal Exploration," Geology 11, 136-40, Washington, D.C. (March).

Moore, R. B. 1992. "Volcanic Geology and Eruption Frequency, Lower East Rift Zone of Kilauea Volcano, Hawaii," Bulletin of Volcanology 54, 475-483.

Moore, R. B., and F. A. Trusdell. 1991. "Geologic Map of the Lower East Rift Zone, Kilauea Volcano, Hawaii," U.S. Geological Survey Miscellaneous Investigations Series, Map I-2225, U.S. Geological Survey, Denver, Colo.

Mullineaux, D. R., D. W. Peterson, and D. R. Crandell. 1987. "Volcanic Hazards in the Hawaiian Islands," pp. 599-624 in Volcanism in Hawaii, ed., R. W. Decker, T. L. Wright, and P. H. Stauffer, Vol. 2, U.S. Geological Survey Professional Paper 1350, Washington, D.C.

Normark, W. R., and H. H. Herring. 1993. "Annotated Bibliography: Marine Geologic Hazards of the Hawaiian Islands with Special Focus on Submarine Slides and Turbidity Currents," U.S. Geological Survey Open-File Report 93-551-C, Menlo Park, Calif.

Pelayo, A. M., and D. A. Wiens. 1992. "Tsunami Earthquakes: Slow Thrust-Faulting Events in the Accretionary Wedge," Journal of Geophysical Research 97 (B11), 15321-37.

Rees, B. A., R. S. Detrick, and B. J. Coakley. 1993. "Seismic Stratigraphy of the Hawaiian Flexural Moat," Geological Society of America Bulletin 105, 189-205.

Richter, D. H., et al. 1970. "Chronological Narrative of the 1959-60 Eruption of Kilauea Volcano, Hawaii," U.S. Geological Survey Professional Paper 537-E, Washington, D.C.

Shepard, F. P., G. A. Macdonald, and D. C. Cox. 1950. "The Tsunami of April 1, 1946," Bulletin of Scripps Institution of Oceanography, 5(6), 391-528. 
Stearns, H. T. 1966. Geology of the State of Hawaii, Pacific Books Publishers, Palo Alto, Calif.

Tilling, R. I., R. Y. Koyanagi, P. W. Lipman, J. P. Lockwood, J. G. Moore, and D. A. Swanson. 1976. Earthquake and Related Catastrophic Events, Island of Hawaii, November 29, 1975, preliminary report, U.S. Geological Survey, Circular 740, Denver, Colo.

Torresan, M. E., W. R. Normark, A. N. Shor, and J. G. Moore. 1988. "Classification of Submarine Failures Surrounding the Hawaiian Islands," EOS, Transactions of the American Geophysical Union 69(44).

USDA (U.S. Department of Agriculture). 1973. Soil Survey of the Island of Hawaï, State of Hawaii, U.S. Government Printing Office, Washington, D.C.

USGS (U.S. Geological Survey). 1986. "Hawaii Volcanoes National Park and Vicinity, Hawaii," U.S. Geological Survey National Park Series (Topographic), Reston, Va.

Winters, W. J., and H. J. Lee. 1982. "Evaluation of Geotechnical Properties and Slope Stability of a Calcareous Ooze on the South-west Slope Off Oahu, Hawaii," U.S. Geological Survey Open-File Report 82-468-B, Menlo Park, Calif., (May).

Wood, H. O. 1914. "On the Earthquake of 1868 in Hawaii," Bulletin of the Seismological Society of America 4, 169-203.

Wyss, M., and R. Y. Koyanagi. 1992. "Isoseismal Maps, Macroseismic Epicenters, and Estimated Magnitudes of Historic Earthquakes in the Hawaiian Islands," U.S. Geological Survey Bulletin 2006, Menlo Park, Calif.

Young, R. W., and E. A. Bryant. 1992. "Catastrophic Wave Erosion on the Southeastern Coast of Australia: Impact of the Lanai Tsunami Ca-105-KA," Geology 20, 199-202. 


\section{LIST OF PREPARERS}

\section{Oak Ridge National Laboratory}

Robert M. Reed, Research Staff, Energy Division Contribution: Project management and review Education: Ph.D., Plant Ecology, 1969, Washington State University

William P. Staub, Research Staff, Energy Division Contribution: Groundwater Education: Ph.D., Geotechnical Engineering, 1969, Iowa State University 
1 
ORNL/TM-12857

\section{INTERNAL DISTRIBUTION}

1. T. J. Blasing

2. G. E. Courville

3. C. E. Easterly

4. F. M. Glenn

5. D. A. Lombardi

6. C. H. Petrich

7. H. D. Quarles, III

8-17. R. M. Reed

18. D. E. Reichle

19. J. W. Saulsbury

20. A. C. Schaffhauser
21. S. M. Schexnayder

22. R. B. Shelton

23. B. M. Sorensen

24. W. P. Staub

25. V. R. Tolbert

26. A. K. Wolfe

27-28. Laboratory Records

29. Laboratory Records-RC

30. Document Reference Section

31. Central Research Library

32. ORNL Patent Section

\section{EXTERNAL DISTRIBUTION}

33. Office of the Assistant Manager for Energy Research and Development, Department of Energy, Oak Ridge Operations, P. O. Box 2001, Oak Ridge, TN 37831

34. Andrea Campbell, Department of Energy, Oak Ridge Operations, Bldg. 2714-J, SE-311, Oak Ridge, TN 37831-8739

35. Virginia H. Goldstein, Director, Hawaii County Planning Commission, 25 Aupuni Street, Room 109, Hilo, HI 96721

36. Charles B. Hamilton, 9023 Fox Lonas Road, Knoxville, TN 37923

37. Hugo Huntzinger, Superintendent, Hawaii Volcanoes National Park, P. O. Box 52, Hawaii Volcanoes National Park, HI 96718-0052

38. Maurice H. Kaya, Energy Program Administrator, Department of Business, Economic Development \& Tourism, 335 Merchant Street, Suite 108, Honolulu, HI 96813

39. Allan J. Jelacic, Office of Renewable Energy Conversion (EE-12), U.S. Department of Energy, Forrestal Building, 1000 Independence Ave. SW, Washington, DC 20585

40-44. Roland R. Kessler, Director, Office of Renewable Energy Conversion (EE-12), U.S. Department of Energy, Forrestal Building, 1000 Independence Ave. SW, Washington, DC 20585

45. Mike Lee, Chief, Operations Division, Honolulu Engineer District, Building 230, Fort Shafter, HI 96858-5440 
46. John Naughton, Pacific Area Office, National Marine Fisheries Service, National Oceanic and Atmospheric Administration, 2570 Dole Street, Honolulu, HI 96822-2396

47. Manuel Nathenson, U.S. Geological Survey, Geologic Division, Branch of Volcanic and Geothermal Processes, 345 Middlefield Road, M/S 910, Menlo Park, CA 94025

48. Robert Smith, Director, Pacific Island Office, U.S. Fish and Wildlife Service, Prince Kuhio Building, Room 6307, 300 Ala Moana Boulevard, Honolulu, HI 96850

49-53. Judith C. Stroud, ER-10, Department of Energy, Oak Ridge Operations Office, P. O. Box 2001, Oak Ridge, TN 37831-6600

54. Carl C. Trettin, Center for Forested Wetland Research, Southeastern Forest Experiment Station, 2730 Savannah Highway, Charleston, SC 29414

55. Lillian D. Trettin, 712 Wakendaw Blvd., Mount Pleasant, South Carolina 29464

56-57. Office of Scientific and Technical Information, P. O. Box 62, Oak Ridge, TN 37831 